\author{
ارزيابى مدلهاى تجربى و هوش مصنوعى در بر آورد تبخير - تعرق \\ مرجع (مطالعه موردى: ايستخاه بروجرد) \\ ياسر سبزوارى' و مهرى سعيدىنيا"

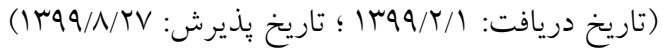

جكيده

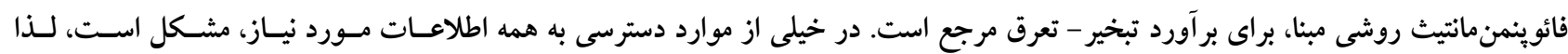

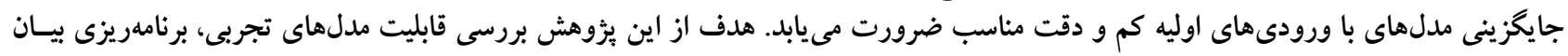

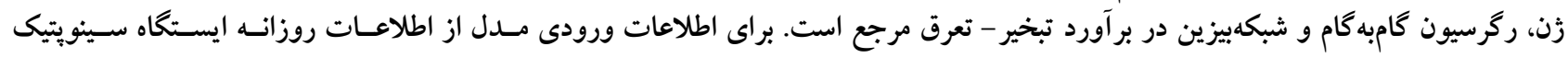

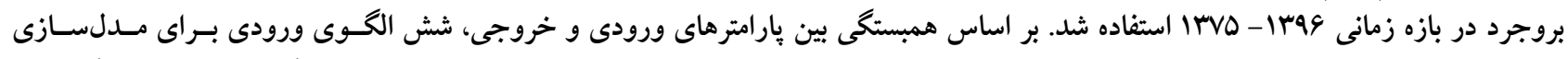

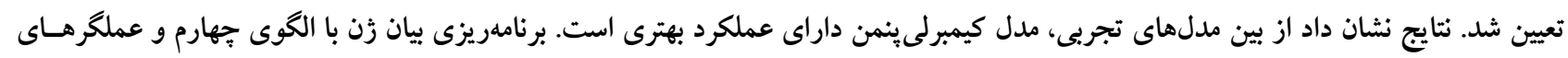

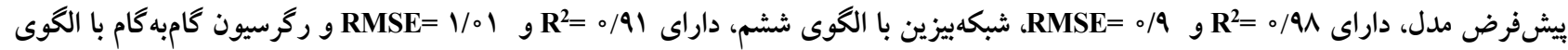

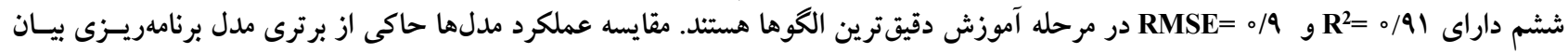

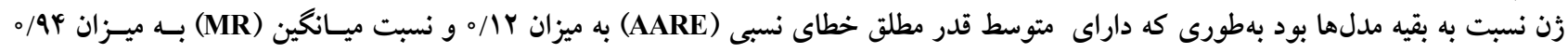

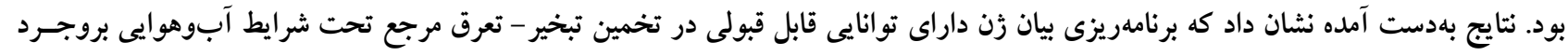

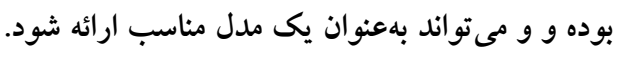

وازمهاى كليدى: فائوينمنمانيث، تبخير - تعرق مرجع، شبكه بيزين، برنامهريزى بيان زن

ו- كروه مهندسى آب، دانشكده كشاورزى، دانشخاه صنعتى اصفهان

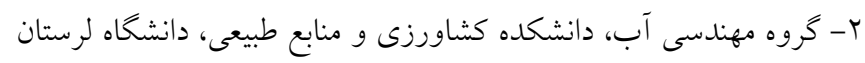

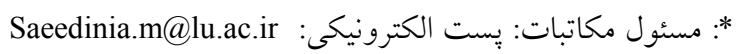


مصنوعى و برنامهريزى بيان زن براى شبيهسـازى تبخيـر تعـرق

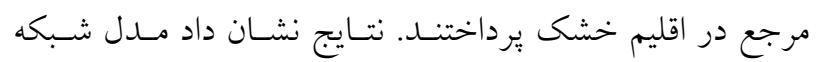

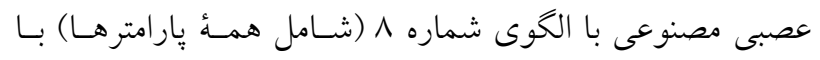

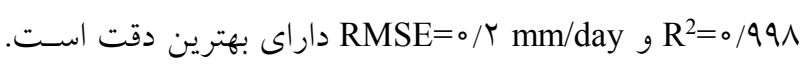

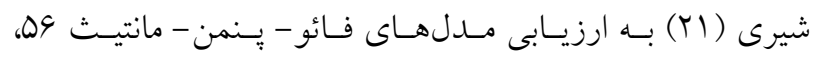
تجربى، نيمه تجربى و برنامهريزى بيان زن در شبيهسـازى تبخيـر

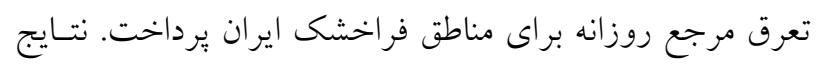

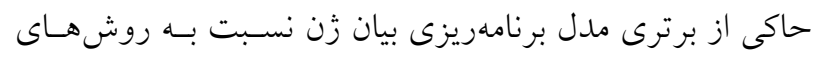

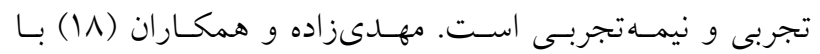

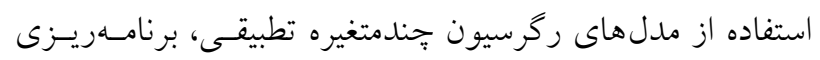

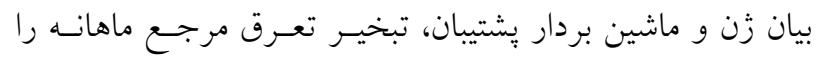

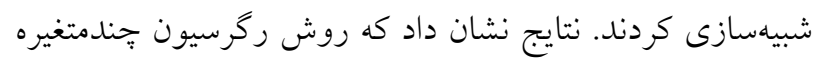
تطبيقى و ماشينبردار يشتيبان با هسته توابع بايه شعاعى بهطسور

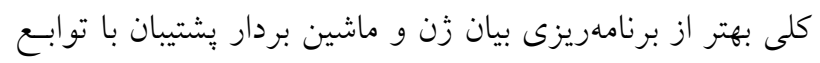

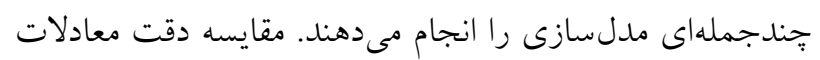

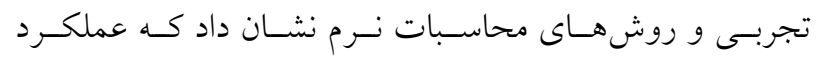

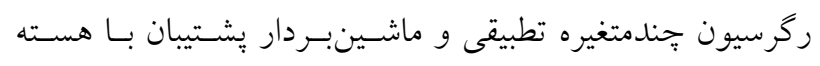

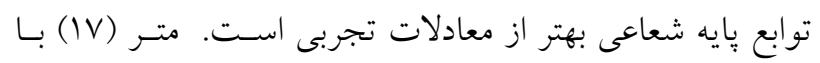

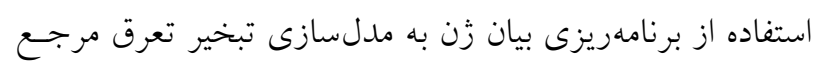

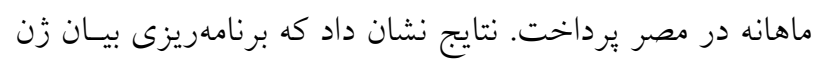

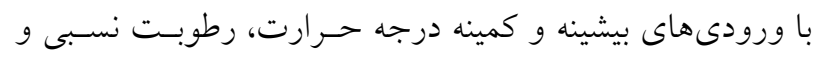

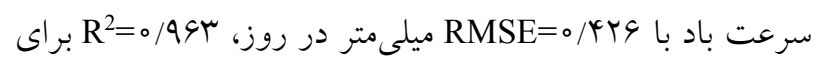

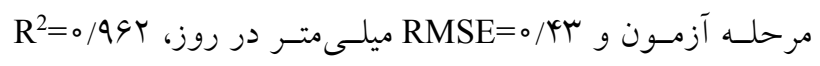

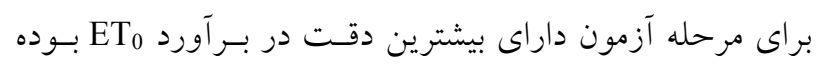

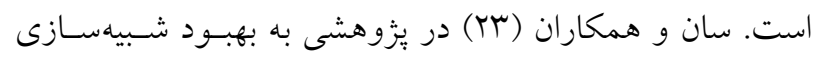

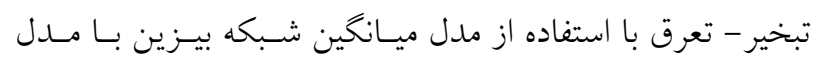

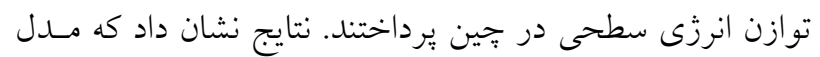

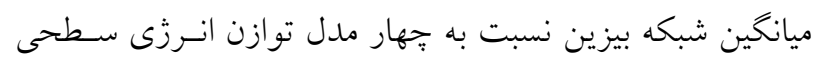

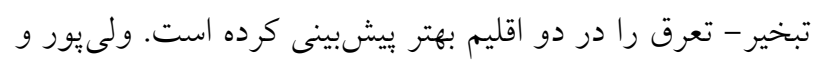

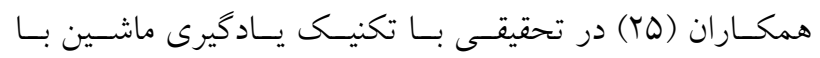

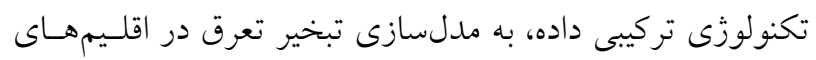

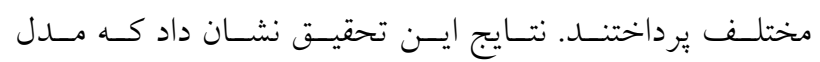

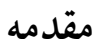

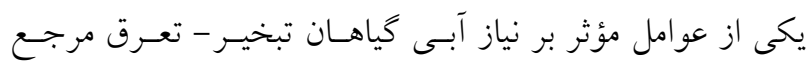

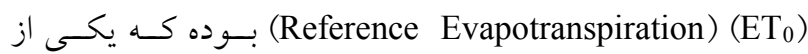
مهم ترين اجزاى جرخهُ هيدرولوزى و تابع متغيرهاى اقليمسى از

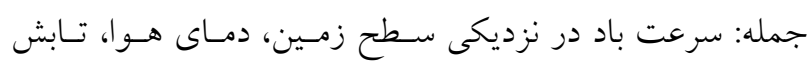

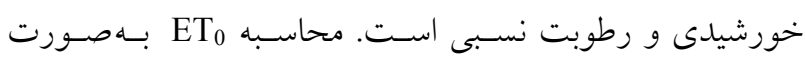

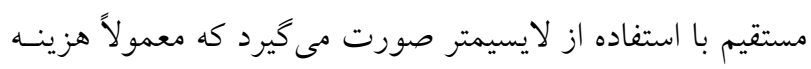

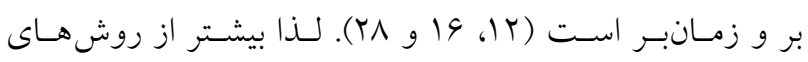

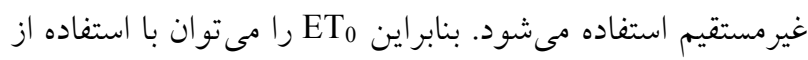

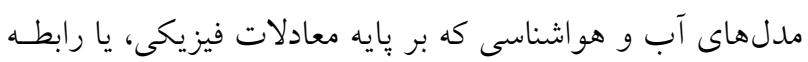
تجربى متغيرهاى هواشناسى هستند، برآورد و شبيهسـازى كـرد.

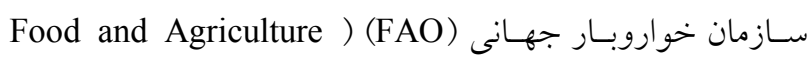
ا Organization بهعنوان معادله استاندارد توصيه كرده است كه ET را بهصورت

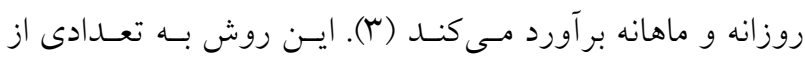

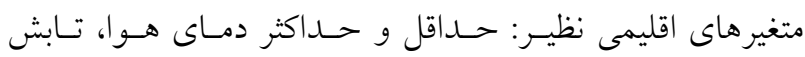

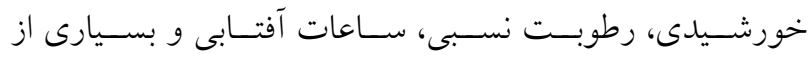

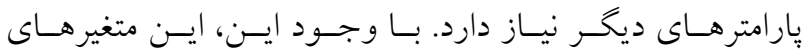
هواشناسى بهخصـوص در كثـورهاى در حسال توسعـه، يـا در

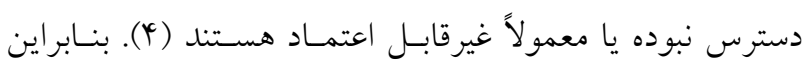

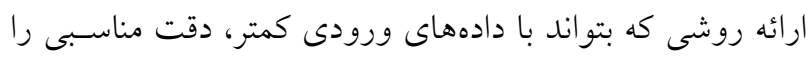

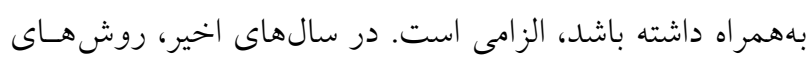

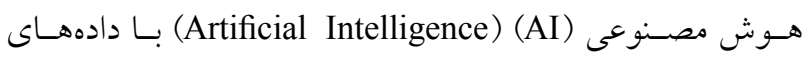

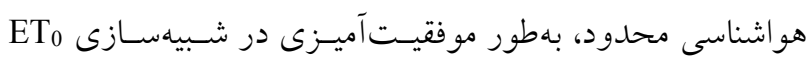

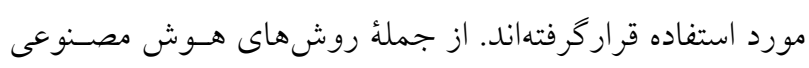

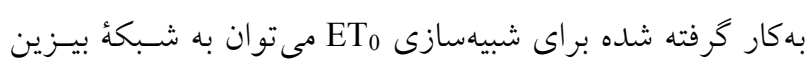

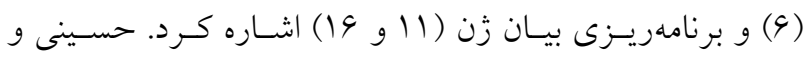

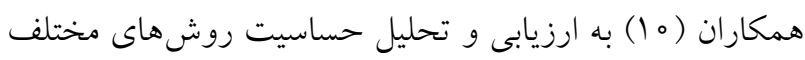

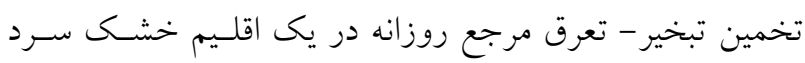

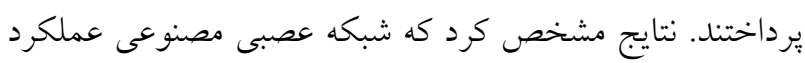

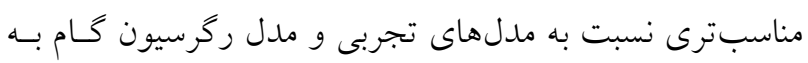

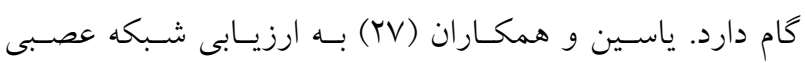


بهمنظور برآورد

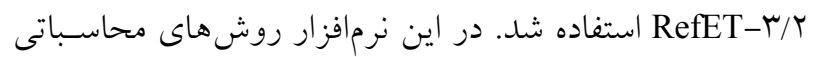
با توجه به نوع دادههاى ورودى (بيشينه و كمينه درجه حرارت،

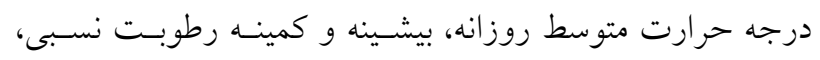

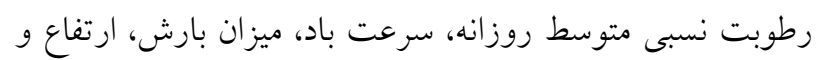

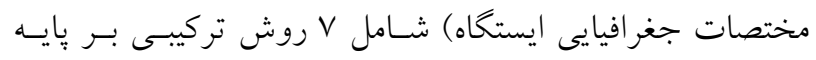

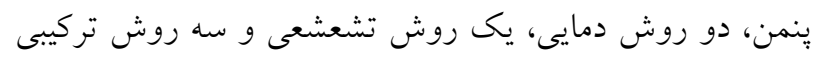

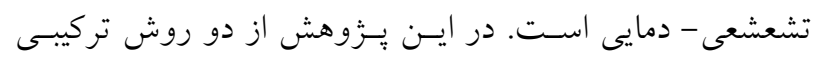

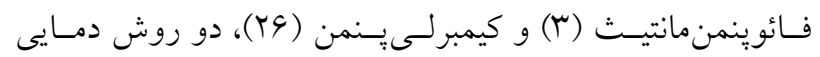

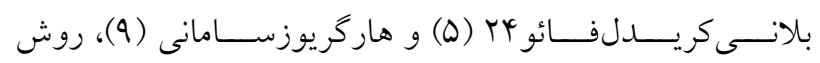

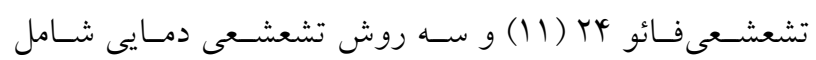

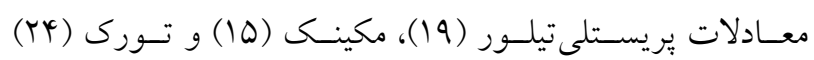

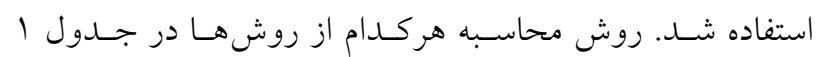
آورده شده است.

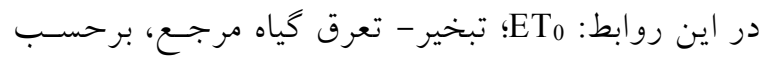

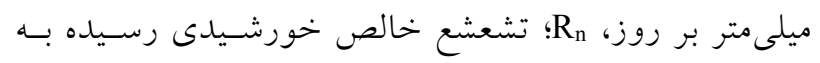

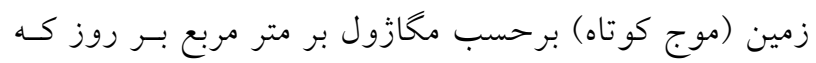

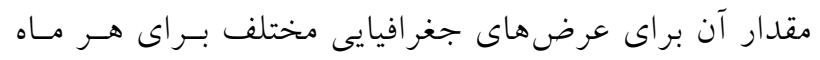

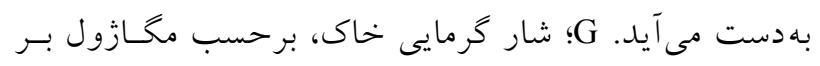

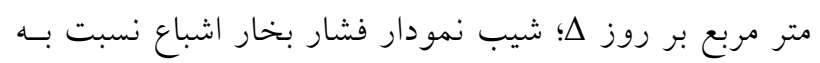

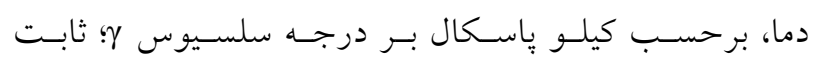

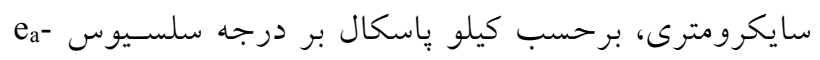

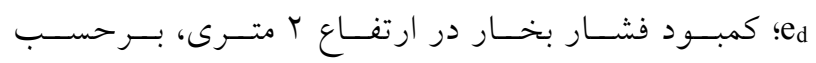

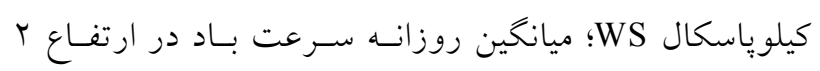

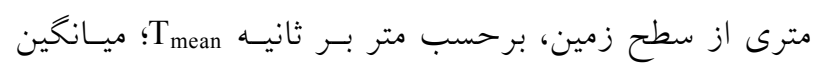

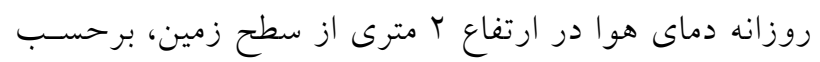

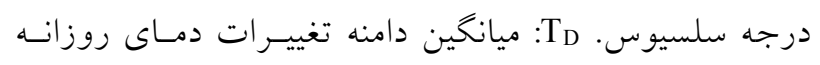

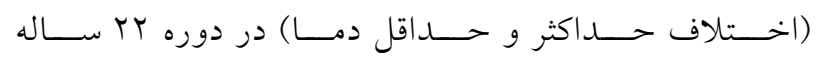

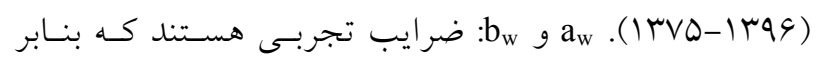

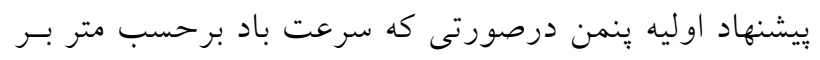

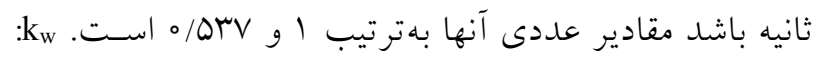
ضريب ثابت برابر به/4 برحسب (ميلىمتر بر روز).

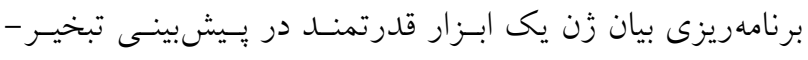

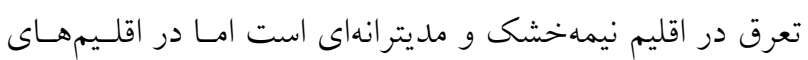

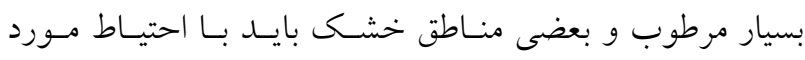

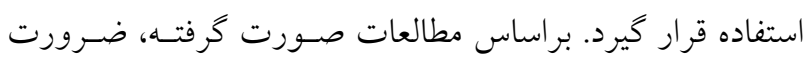

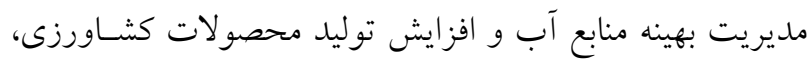

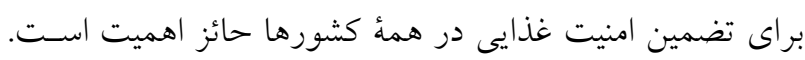

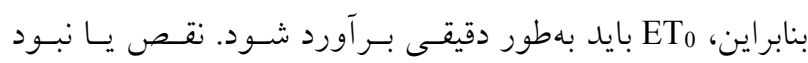

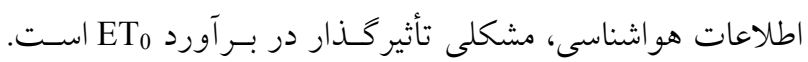

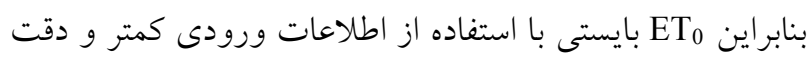

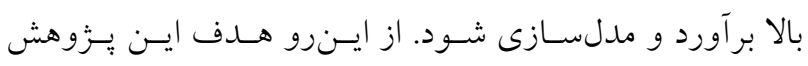

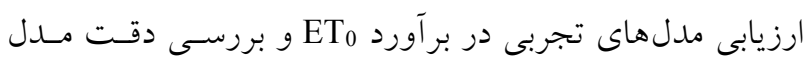

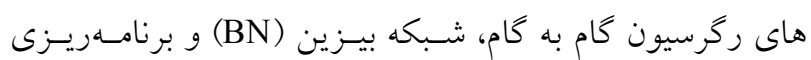
بيان زن (GEP) در برآورد ET

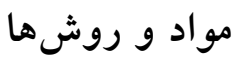
معرفى منطقه مورد مطالعه و اطلاعات مورد استفاده

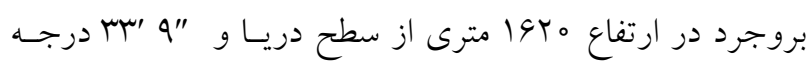

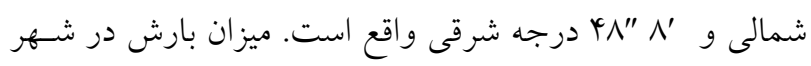

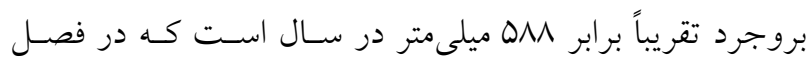

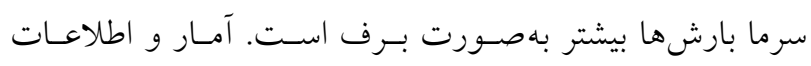

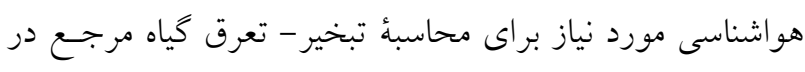

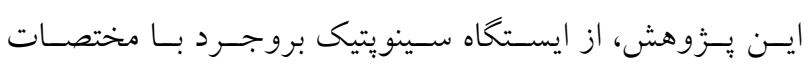

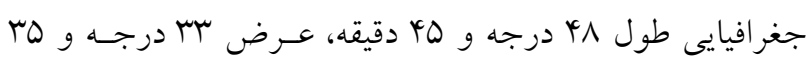

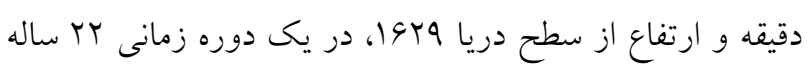

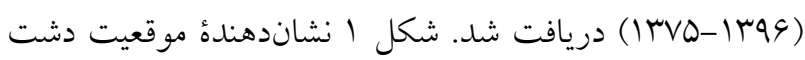

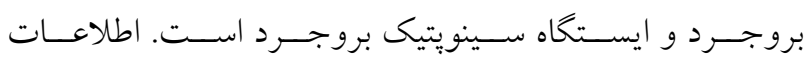

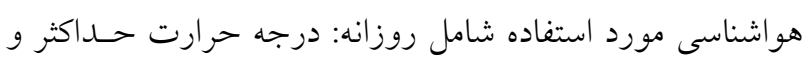

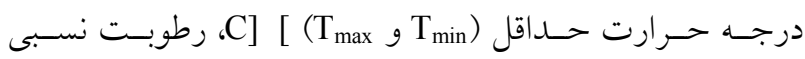

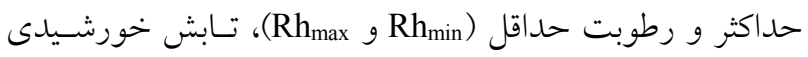
[ms $\left.{ }^{-1}\right]$ (WS) و سرعت باد در ارتفاع دو مترى بهمنظور مقايسه [ ET 


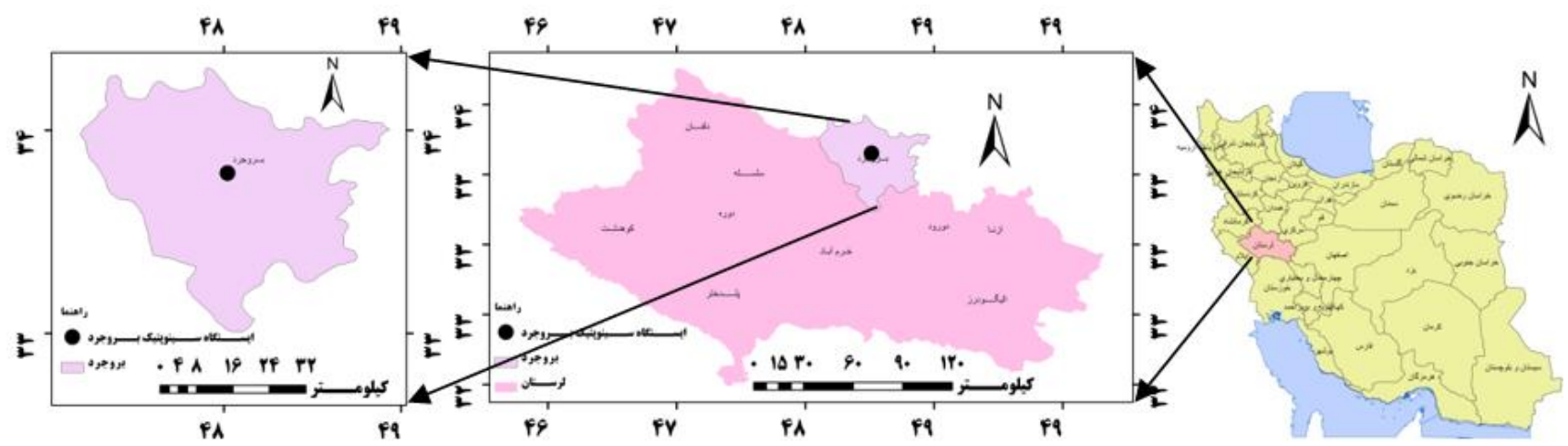

شكل 1. موقعيت جغرافيايى بروجرد در استان و كثور

جدول ا. مدلهاى تجربى برآورد تبخير - تعرق مرجع

\begin{tabular}{|c|c|c|}
\hline شكل معادله & نام روش محاسبه ET0 & رديف \\
\hline $\mathrm{ET}_{0}=0.0023 \mathrm{R}_{\mathrm{n}}\left(\mathrm{T}_{\text {mean }}+17.8\right) \mathrm{T}_{\mathrm{D}}^{0.5}$ & هارگريوز سامانى (9) & 1 \\
\hline $\mathrm{ET}_{0}=\mathrm{a}+\mathrm{b}\left[\mathrm{P}\left(0.46 \mathrm{~T}_{\text {mean }}+8.13\right)\right]$ & بلانى كريدلفائو ب M (D) & r \\
\hline $\mathrm{ET}_{0}=0.61 \frac{\Delta}{\Delta+\gamma} \cdot \frac{\mathrm{R}_{\mathrm{s}}}{2.45}-0.12$ & مكينى (ه) & r \\
\hline $\mathrm{ET}_{0}=\mathrm{a}_{\mathrm{T}} \times 0.013 \frac{\mathrm{T}_{\text {mean }}}{\mathrm{T}_{\text {mean }}+15} \times \frac{23.8856 \mathrm{R}_{\mathrm{s}}+50}{\lambda}$ & تورك-1991 (YY) & $r$ \\
\hline $\mathrm{ET}_{0}=1.26 \frac{\Delta}{\Delta+\gamma} \cdot \frac{\mathrm{R}_{\mathrm{n}}-\mathrm{G}}{\lambda}$ & يريستلىتيلور (19) & 0 \\
\hline $\mathrm{ET}_{0}=\frac{\Delta}{\Delta+\gamma}\left(\mathrm{R}_{\mathrm{n}}-\mathrm{G}\right)+\mathrm{k}_{\mathrm{w}} \frac{\gamma}{\gamma+\Delta}\left(\mathrm{a}_{\mathrm{w}}+\mathrm{b}_{\mathrm{w}} \mathrm{u}_{2}\right)\left(\mathrm{e}_{\mathrm{s}}-\mathrm{e}_{\mathrm{o}}\right) / \lambda$ & معادله اصلاح شده ينمن توسط كيمبرلى 1919 (Y4) & 4 \\
\hline $\mathrm{ET}_{0}=\mathrm{a}+\mathrm{b}\left[\frac{\Delta}{\Delta+\gamma} \cdot \mathrm{R}_{\mathrm{s}}\right]$ & تابشى فائو (11) & V \\
\hline $\mathrm{ET}_{0}=\frac{\left[0.408\left(\mathrm{R}_{\mathrm{n}}-\mathrm{G}\right)+[(900 \gamma) /(\mathrm{T}+273)] \times \mathrm{U}_{2} \times\left(\mathrm{e}_{\mathrm{a}}-\mathrm{e}_{\mathrm{d}}\right)\right]}{\Delta+\gamma \times\left(1+0.34 \mathrm{U}_{2}\right)}$ & فائو ينمن مانتيث (r) & $\wedge$ \\
\hline
\end{tabular}

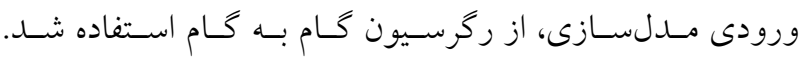

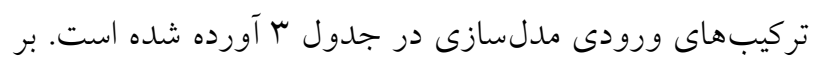
اساس همبستكى بين خارامترهاى اقليمى مختلف و

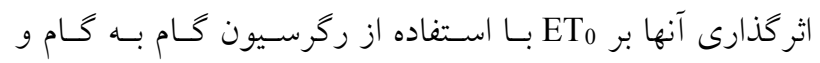
ترتيب ورود اين پارامترها در مدلسازى، 9 الخوى ورودى براى ارزيابى تركيبهاى مختلف تعيين شد.

$$
\text { مدل رگرسيون گام به گام }
$$

با اين روش مىتوان بهطور همزمان بـه تحليـل و بررسسى جنــ متغير مختلف يرداخت. ركرسيون كام به گام درواقع، رابطه بـين جند متغير بيشبين با متغير پِاسخ مـورد نظـر را بيـان مسى كنــ.
در اين بززوهش اطلاعـات مـورد اسـتفاده متشـكل از دو دســـ دادههاى آموزش و دادههاى آزمون هستند. دادههاى آمـوزش در هنخام آموزش مدل مورد استفاده قرار مى گيرند، به ايـن ترتيـب

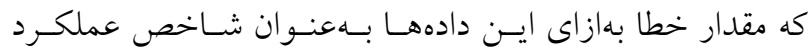
مدلها درنظر كرفته مىشود. دادههاى آزمون بِ از از اتمام فرايند آموزش و براى ارزيابى عملكرد مدلها در تعمـيم نتـايج، مـورد

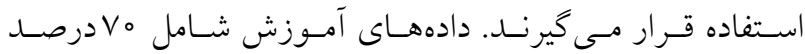

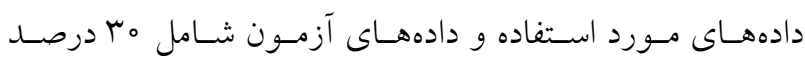
باقيمانده دادههاى مورد استفاده اسـت. جــدول آ، نشـاندهنــده يارامترهاى آمارى دادههاى مورد اسـتفاده اسـتـ. بــراى بررسىى

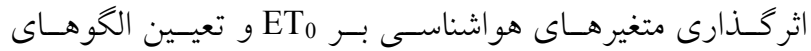


جدول r. آمار توصيفى دادههاى مورد استفاده

\begin{tabular}{|c|c|c|c|c|c|c|c|}
\hline ميانخين & انحراف معيار & حداقل & حداكثر & كشيدگى & جولى جیى & متغير & \\
\hline rI/YA & $11 / r r$ & $-\Lambda / \Lambda^{+}$ & $|4| / 4$ & $-0 / 1 \wedge$ & $-1 / 09$ & Tmax & \multirow{7}{*}{ دادههاى } \\
\hline$\Lambda / \mu I$ & N/T & $-r \mid / K$ & TV & $-0 / Y 1$ & $-\circ / \mathrm{VI}$ & Tmin & \\
\hline$\Delta \Lambda$ & TY/OT & Mr & 100 & $\circ / 1$ & $-1 / 4$ & RHmax & \\
\hline TS/OY & $1 N / 4$ & 1 & 94 & $1 / 14$ & س & RHmin & \\
\hline r/rq & $1 / \Lambda V$ & 。 & $I r / A V$ & $0 / 99$ & $1 / 0 V$ & WS & \\
\hline $1 / 4 q$ & r/gr & 。 & $1 r / \Lambda$ & $-0 / 94$ & $-0 / 1 r$ & $\mathrm{~N}$ & \\
\hline $4 / 99$ & T/99 & $\circ / \mu$ & $1 r / 1$ & $0 / Y 4$ & $-1 / 14$ & ET0 & \\
\hline$Y 1 / 9 \Lambda$ & $11 / 11$ & -10 & 41 & $-0 / 1 \mu$ & $-1 / 10$ & Tmax & \multirow{7}{*}{ دادههاى آزمون } \\
\hline$\Lambda / \Delta Y^{c}$ & $\Lambda / I V$ & $-r \circ / \varphi$ & $r G / r$ & $-0 / 1 r$ & $-0 / \wedge \Delta$ & Tmin & \\
\hline$\Delta V / V$ & $T Y / D$ & 10 & 100 & $\circ / \wedge$ & $-1 / r q$ & RHmax & \\
\hline TA/MD & $\mathrm{N} / \circ \mathrm{V}$ & 。 & 90 & $1 / \circ \wedge$ & ०/OT & RHmin & \\
\hline ס ט & $1 / \Lambda \Lambda$ & 。 & ir & $\circ / 91$ & $1 / D F$ & WS & \\
\hline$\Lambda / r V$ & $r / 9 V$ & 。 & Ir & $-0 / \wedge \varphi$ & $-0 / \mu 1$ & $\mathrm{~N}$ & \\
\hline $4 / 99$ & $r / \Delta \Delta$ & $0 / 4 q$ & $9 V / T$ & V/VY & $-1 / 44$ & ET0 & \\
\hline
\end{tabular}

جدول r. الخوهاى ورودى شبكه بيزين و برنامهريزى بيان زن

\begin{tabular}{|c|c|c|}
\hline الكوى ورودى مدل & 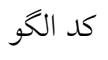 & رديف \\
\hline $\mathrm{ET} 0=\mathrm{f}\{\mathrm{Tmax}\}$ & M1 & 1 \\
\hline $\mathrm{ET} 0=\mathrm{f}\{\mathrm{Tmax}, \mathrm{WS}\}$ & M2 & r \\
\hline $\mathrm{ET} 0=\mathrm{f}\{\mathrm{Tmax}, \mathrm{WS}, \mathrm{N}\}$ & M3 & r \\
\hline $\mathrm{ET} 0=\mathrm{f}\{\mathrm{Tmax}, \mathrm{WS}, \mathrm{N}, \mathrm{Tmin}\}$ & M4 & r \\
\hline $\mathrm{ET} 0=\mathrm{f}\{\mathrm{Tmax}, \mathrm{WS}, \mathrm{N}, \mathrm{Tmin}, \mathrm{Rhmin}\}$ & M5 & $\Delta$ \\
\hline $\mathrm{ET} 0=\mathrm{f}\{\mathrm{Tmax}, \mathrm{WS}, \mathrm{N}, \mathrm{Tmin}, \mathrm{Rhmin}, \mathrm{Rhmax}\}$ & M6 & 4 \\
\hline
\end{tabular}

متغير هاى بيشبين، متغيرهايى هستند كه بـا بهــرهيـرى از آنها متغير ديخر بيشبينى شده و متغير وِاسخ متغيرى است كـه مـورد در صورت نقض اين دو فرض معادله ركرسـيونى را نمسىتـوان

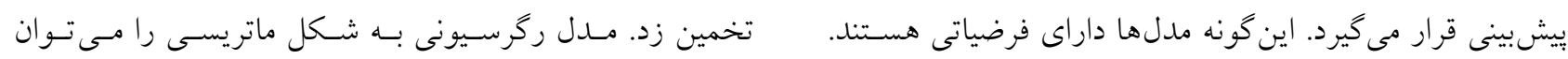
فرضهايى كه رگرسيون گام به گام را از رگرسيون ساده متمـايز بلهصورت معادله زير نشان داد:

$\mathrm{Y}=\mathrm{X} \beta+\mathrm{e}$

كه م ماتريس ضرايب ركرسيونى كه ضرايب نامشخصى هستند كه در حقيقت، مسئول برآورد يُارامتر پِاسخ هسـتند، e مـاتريس خطاى برازش و Y نيز ماتريس وِاسخ است. با حـل معادلـه (1)

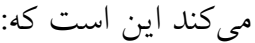

() تعداد متغيرهاى ييشبين (مستقل) در ركرسيون بايد كمتـر از تعداد مشاهدات باشد. Y) همبستخى خطى كامل بين متغيرهاى بيشبين و پِاسخ وجـود 
عمـل مى كند كه اين سـاختارهاى درختسى از مجموعسه توابـع

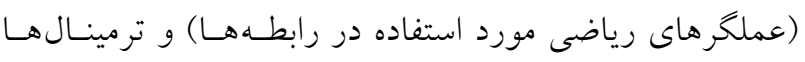
(متغيرهاى مسئله و اعداد ثابت) ايجاد مى شوند (N).

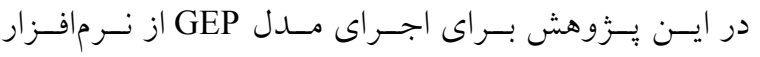
Genexprotools 5

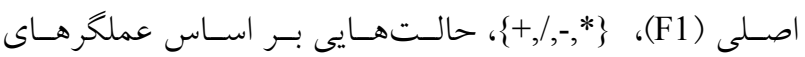

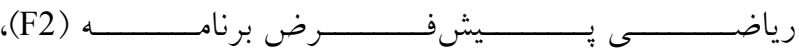
, Sin.Cos,Atan $\}$

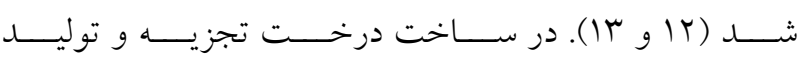
جمعيت اوليه، از راهحل هاييى كه از تركيـب تصـادفى مجموعسه توابع (عملكرهاى رياضى مورد استفاده در روابط) و ترمينـالهـا (متغيرهاى مسئله و اعداد ثابت) ايجاد مىشوند، استفاده شد. در ابتداى اجراى مدل GEP، بايد تعداد زنها و كرومـوزوم ها مشخص شود. با توجه به مطالعات انجام شده قبلى، بهتـرين جمعيت از مبتا •ها كروموزوم و ياسخ مناسب از انتخاب ب يـا

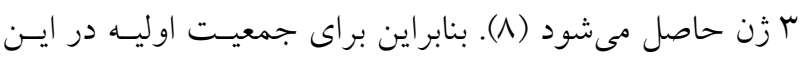

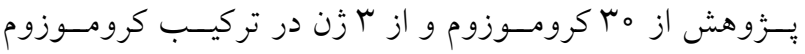
استفاده شد. همجينين تابع بيوند (+) بـهعلـت برتـرى بـر ديخـر توابع انتخاب شد. حداكثر تكرار تابع برازش هـم هـ ما تعيسين

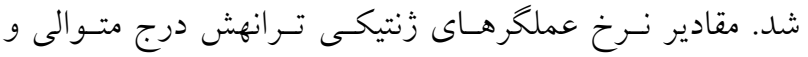
ترانهش ريشه درج متوالى برابر //ه، نرخ جهش و نـرخ وارون-

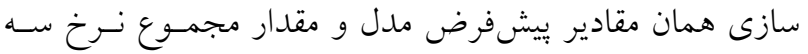
عملكر تركيب تك نقطهاى، تركيـب دو نقطـهاى و تركيـبـ زن،

$$
\text { طبق نظر فريرا (^) برابر V/ه تعيين شد. }
$$

\section{شبكه بيزين}

شبكه بيزين ملدلى گرافيكى احتمالى است (Y | ( ) كه يك نمـايش

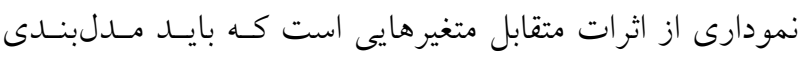
شوند، بهطورى كه علاوه بر كيفيت رابطه بين متغيرهاى مسـئله، كميت ارتباط بين اين متغيرها را نيز به نمـايش مسى كـذارد (V). ايسن روش بــر مبنــاى محاسـبات قـانون بيـز اسـت. قـانون بيـز بهصورت رابطه زير نشان داده شده است:
برحسب $\beta$ خواهيم داشت:

$\beta=\left(X^{\prime} X\right)^{-1}\left(X^{\prime} Y\right)$

كه در رابطه بالا، X $D$ ترانهاده ماتريس X است. براى محاسبـ معكوس (X'X) لازم است متغيرهاى مستقل همبستخى زيـادى نداشته باشند، زيرا در اين صورت ماتريس (X'X) را نمىتـوان معكوس كرد و باعث افزايش خطا در اثر خـرد كـــدن دادههـا و محاسبات مىشود. در اين مطالعه براى انجام تحليـل رگرسـيون كام به كام از نرمافزار SPSS-24 استفاده شد.

\section{برنامهريزى بيان زن}

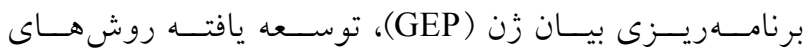
برنامهريزى زنتيك (GP) و الخوريتم زنتيك (GA) است كه در سال 1999 توسط فريرا (N) بر اسـاس تئسورى دارويـن ابــاع شد. حالتهاى مختلف تركيبهاى زنها را زنوتيـٍِ (در ايسن مطالعه تركيب هاى مختلف از يارامترهاى هواشناسى) و نتـايج حاصل از حالتهاى مختلف تركيب هاى زنها را فنوتيسبِ (در

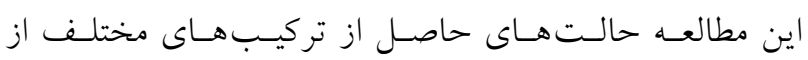

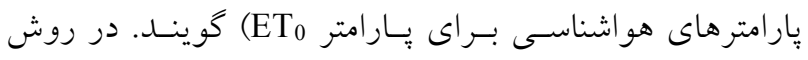
برنامهريزى بيان زن، كروموزومهــاى خطى و سـاده بـا طــول ثابت، مشابه با الخــوريتم زنتيــى و ســاختارهـاى شـاخهاى بــا انــازه و شـكل هــاى متفــاوت، مشـابه بـا درختــان تجزيـه در برنامهريزى زنتيك تركيب مىشوند. در ايسن روش زنوتيـيٍ و فنوتيبٍ از هم جدا شده و سيستم قـادر خواهـد بــود از تمـام مزاياى تكاملى بهره كيرد. بـا وجــود اينكـهـ فنوتيـبّ در GEP مشابه ساختار شـاخهاى GP اسـت، امـا سـاختار شـاخهاى در كه بيان درختى نيز ناميده مىشود، بيانخر تمام زنومهـاى GEP مستقل است. در مجموع، در GEP بهسـازى در يـك سـاختار خطى اتفاق افتاده و سـيس بـهـصورت سـاختار درختسى بيـان مىشود. اين امر سبب خواهد شد كه تنها زنوم اصلاح شده به نسل بعد انتقال يابد و نيازى به سـاختارهاى سـنخين تكثيـر و جهش نباشد. برنامه ريزى بيان زن بــرخلاف الخــوريتم زنتيـك روى ساختار درختى رابطهها بهجاى سلسـله ارقــام دودويسى 
بالاترين امتياز بهعنوان ساختار مورد نظــر انتخـاب مسى شــود

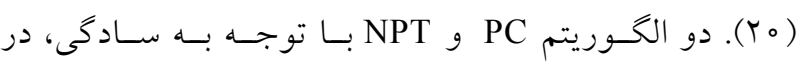
شبكههاى بيزين براى آموزش ساختار مدل سازى بيشتر مورد

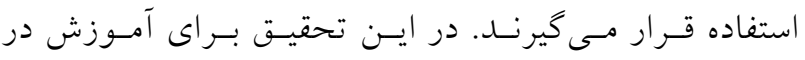

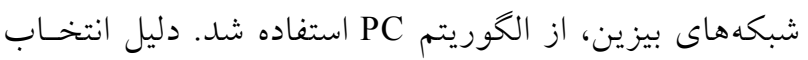

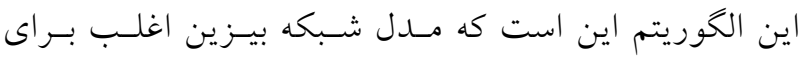
مدل سازى دادههاى كيفى استفاده مى شود. با توجه به ماهيت

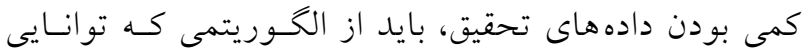

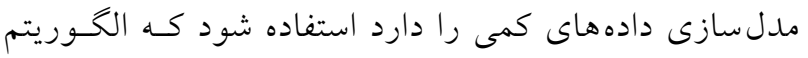
Pاراى اين قابليت است. در اين الكوريتم، مجموعهاى از PC

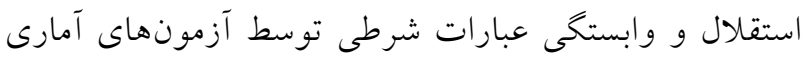

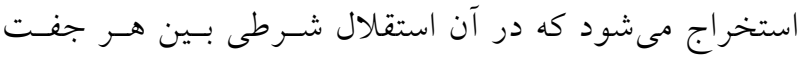
متغير وجود نداشته و جهـت كمـانهـا بـر اسـاس استقلال شرطى تعيين مى شود. شبكه بيزين علاوه بر بيشبينس متغيـر

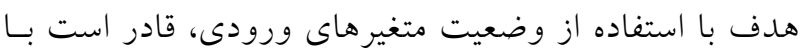
در دست داشتن وضعيت متغير بيشبينى شونده، ميزان تـأثير

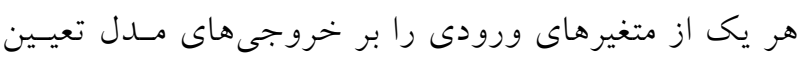

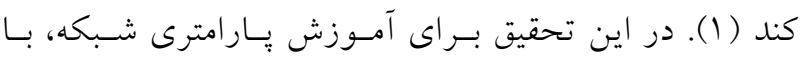
تنظيم دو متغيـر سـطح معنسى دارى (Significance Level) و

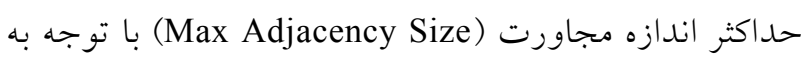

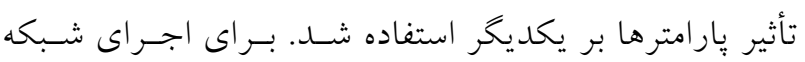

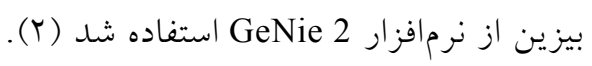

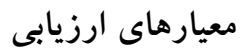

بهمنظور ارزيابى دقت و كاريى مــلهــا، از معيارهـاى ضـريب

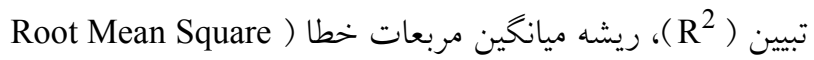

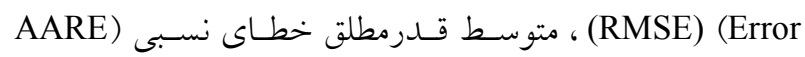
(Average Absolute Relative Error)

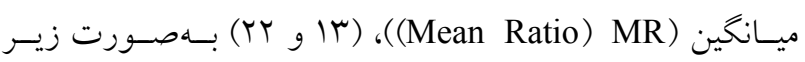

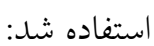

$$
\text { RMSE }=\sqrt{\frac{1}{N} \sum_{i=1}^{N}\left(X_{i}-Y_{i}\right)^{2}}
$$

$\mathrm{P}(\mathrm{b} \mid \mathrm{a})=\mathrm{P}(\mathrm{a} \mid \mathrm{b}) \times \frac{\mathrm{P}(\mathrm{b})}{\mathrm{P}(\mathrm{a})}$

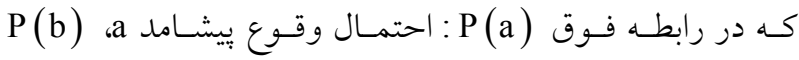

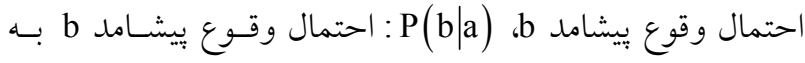

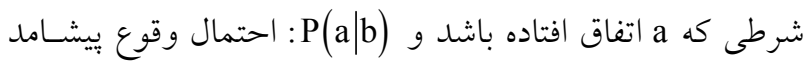
a بهشرطى كه b اتفاق افتاده باشد، هستند.

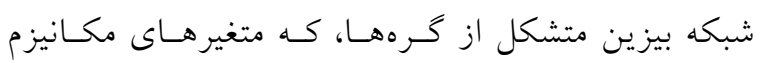

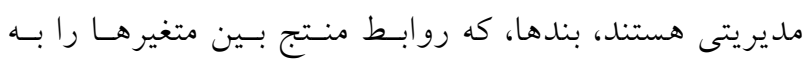

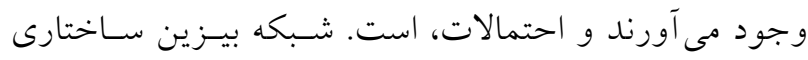

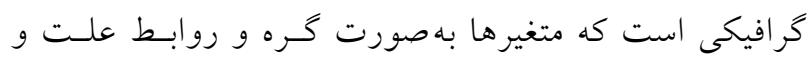

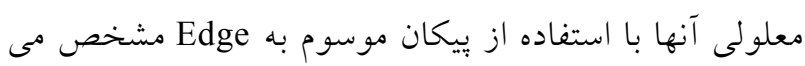

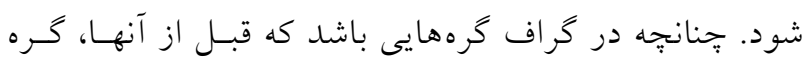

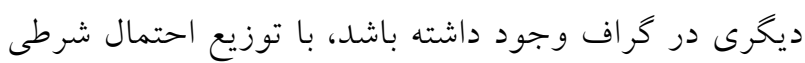
تعريف مى شوند، در غير اين صورت با احتمال آغازين بيـان مى شوند. بايين ترين بخش در شبكه بيـزين از طريـق قـانون

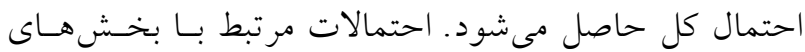
بالايى شبكه بر اساس قانون بيز هستند. در حالت كلسى، اخـر

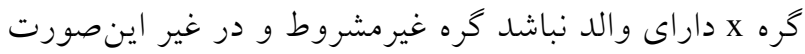

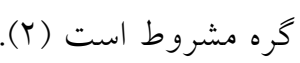
در مورد ساختار شبكه بيزين اخر مجموعهاى شامل n متغيــر بهصورت

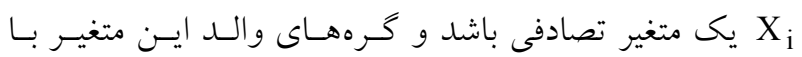

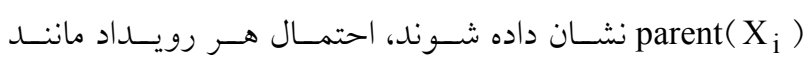

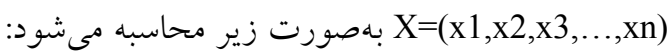

$\mathrm{P}\left(\mathrm{x}_{1}+\mathrm{x}_{2}+\ldots . .+\mathrm{x}_{\mathrm{n}}\right)=\prod^{\mathrm{n}} \mathrm{P}\left(\mathrm{x}_{\mathrm{i}} \mid\right.$ parents $\left.\left(\mathrm{x}_{\mathrm{i}}\right)\right)$ الكوريتمهاى يادگيرى شبكه بيزين به الكوريتمهاى ياد كيرى

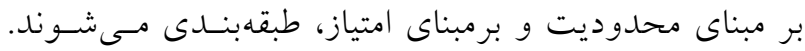
دسته اول بر اساس استقلال شرطى و وابستكى بين متغيرهـا، توسط آزمونهاى آمارى بهدست مى آيد (مانند الكوريتمهـاى Necessary Path ) NPT gath condition) PC Condition ). در روش هاى يادگيرى بر مبناى امتياز نيز همه

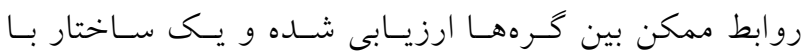




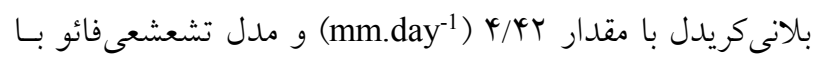

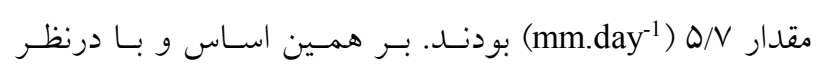

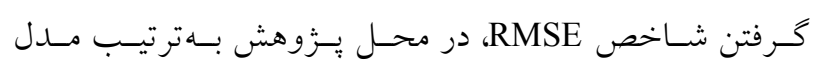

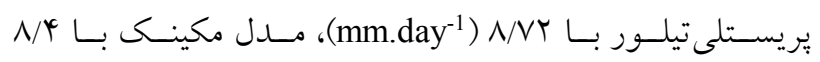

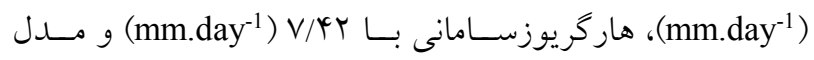

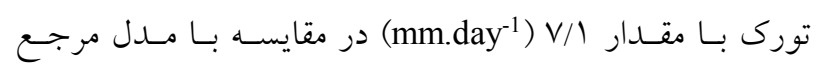

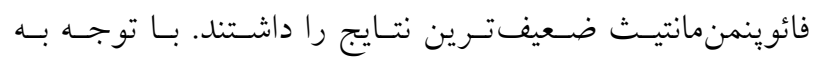

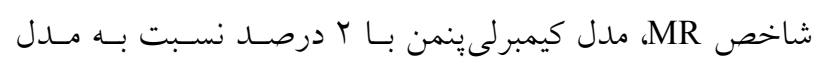

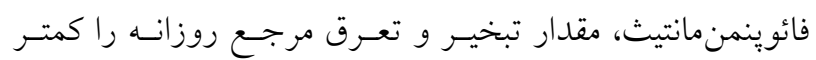

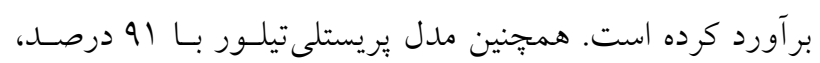

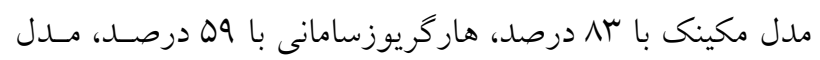

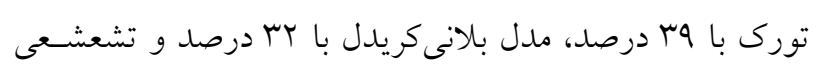

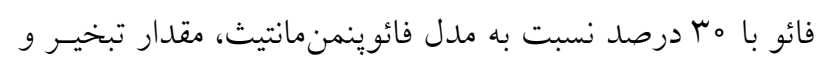

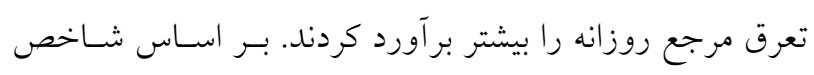

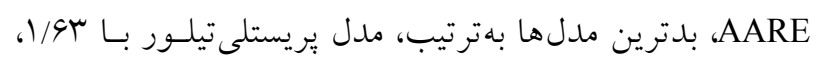

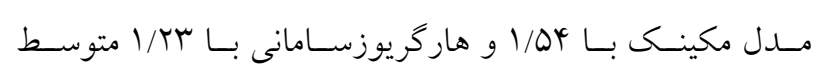

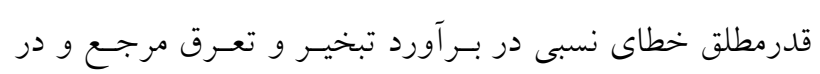

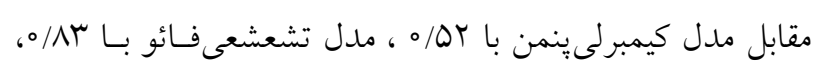

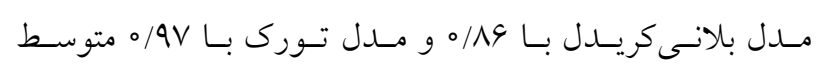

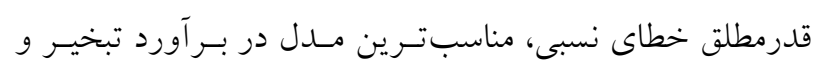

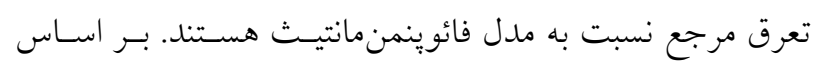

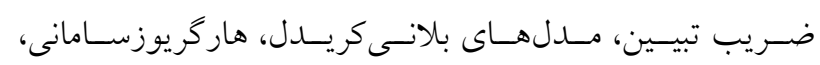

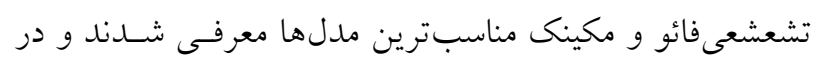

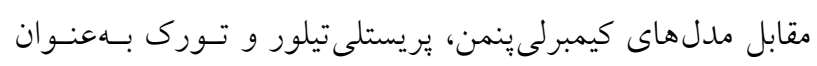

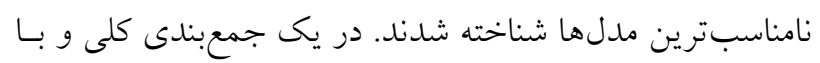

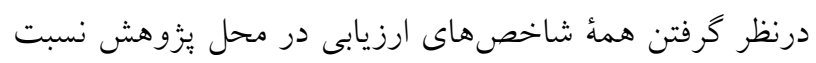

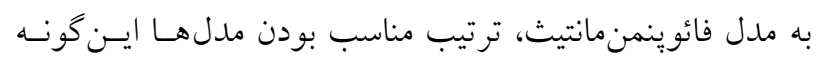

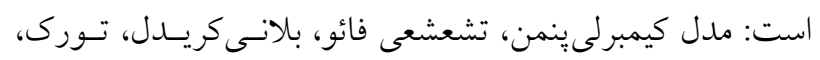

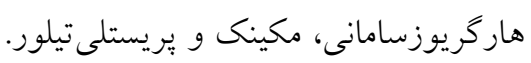

$$
\text { ركرسيون گام به گام }
$$

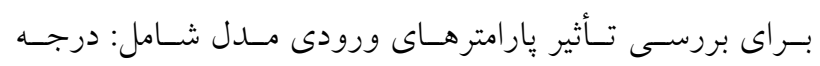

$R^{2}=\left(\frac{\sum_{i=1}^{N}\left(X_{i}-\bar{X}\right)\left(Y_{i}-\bar{Y}\right)}{\sqrt{\sum_{i=1}^{N}\left(X_{i}-\bar{X}\right)^{2} \sum_{i=1}^{N}\left(Y_{i}-\bar{Y}\right)^{2}}}\right)^{2}, 0 \leq R^{2} \leq 1$

$\operatorname{AARE}=\frac{1}{\mathrm{n}} \sum_{\mathrm{i}=1}^{\mathrm{n}} \frac{|\mathrm{xi}-\mathrm{yi}|}{\mathrm{yi}}$

$\mathrm{MR}=\frac{1}{\mathrm{n}} \sum_{\mathrm{i}=1}^{\mathrm{n}} \frac{\mathrm{x}_{\mathrm{i}}}{\mathrm{y}_{\mathrm{i}}}$

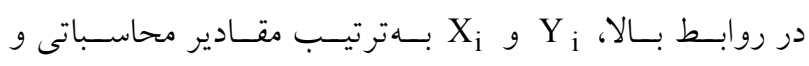

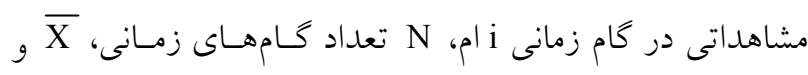
نيز بهترتيب ميانخين مقادير مشاهداتى و محاسباتى اسـت

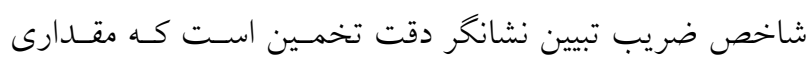

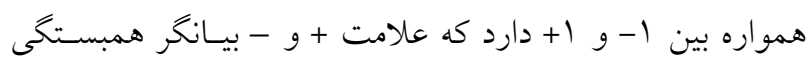

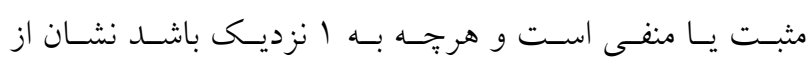
همبستكى بيشتر بين مقادير مشاهداتى و محاسـباتى دارد. آمـاره

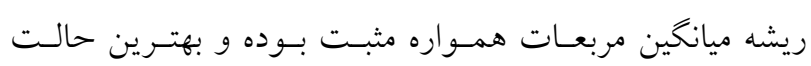

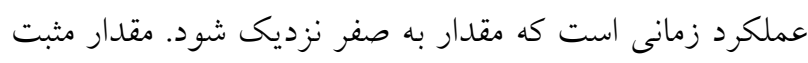

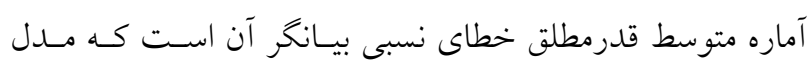

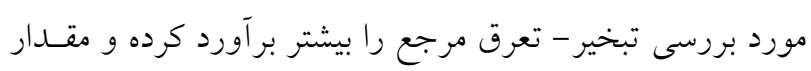

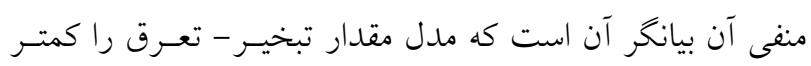

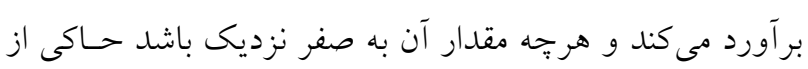

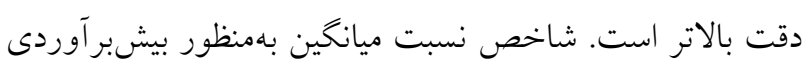

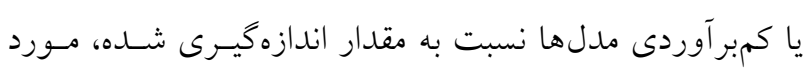

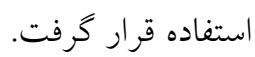

\section{نتايج و بحث}

\section{ارزيابى مدلهاى تجربى برآورد تبخير و تعرق مرجع}

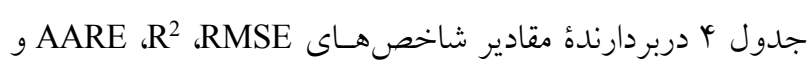

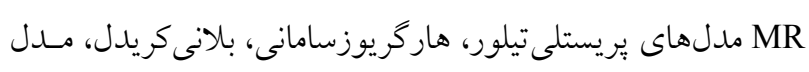

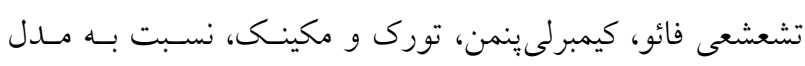

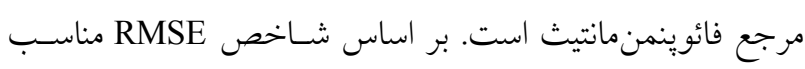

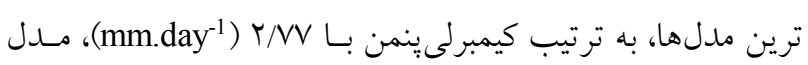


جدول f. ارزيابى عملكرد هفت مدل بر آورد تبخير و تعرق مرجع نسبت به مدل فائو-ينمن -مانتيث

\begin{tabular}{|c|c|c|c|c|c|}
\hline$\left(\mathrm{mm}\right.$ day $\left.^{-1}\right)$ RMSE & AARE & MR & $\mathrm{R}^{2}$ & مدل & رديف \\
\hline$\Lambda / V Y$ & $1 / 94$ & $1 / 91$ & o/N & ير يستلى - تيلور & 1 \\
\hline V/AT & $1 / \pi r$ & $1 / 09$ &.$/ 90$ & هار خريوز - سامانى & r \\
\hline YAT & ०/A9 & $1 / \mu r$ &.$/ 99$ & بلانى كريدل & r \\
\hline$\Delta / N$ & 。/Ar & $1 / r$ &.$/ 90$ & تشعشعى فائو & $r$ \\
\hline$T / \mathrm{VV}$ &.$/ Q T$ & $\circ / 91$ & -/Ar & كيمبرلى - بينمن & 0 \\
\hline V/I & $\circ / 9 V$ & $1 / 149$ & $\circ / M$ & تورى ت ت & 9 \\
\hline$\Lambda / 4$ & $1 / Q F$ & I/Ar &.$/ 94$ & مكينك & V \\
\hline
\end{tabular}

جدول هـ مقدار ضرايب دقت مدل و بارامترهاى رگرسيون گام به گام

\begin{tabular}{|c|c|c|c|c|c|}
\hline \multirow[t]{3}{*}{ ضريب همبستكى :جند كانه } & 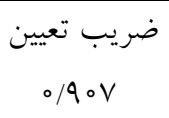 & ضريب تعيين تصحيح شده & \multicolumn{2}{|c|}{ خطاى معيار شبيهسازى } & \\
\hline & \multicolumn{2}{|c|}{ ضرايب استاندارد نشده } & \multirow{2}{*}{ ضر ايب استانداردشده } & \multirow{2}{*}{$\mathrm{t}$} & \multirow{2}{*}{ سطح معنى دارى } \\
\hline & $\mathrm{B}$ & خطاى معيار & & & \\
\hline (Constant) & $-\circ / \Delta \Delta r$ & -/TRO & & $-4 / 4 \mid r$ & 。 \\
\hline Tmin & $0 / 09 V$ & $\circ / \circ \circ \Delta$ & $\circ / \wedge \wedge \vee$ & $1 \% / 94 \pi$ & 。 \\
\hline Tmax & $0 / 144$ & $\circ \% \circ \mathrm{V}$ & ./QT & rq/৭१५ & 。 \\
\hline Rhmin & \%००Y & $0 / 009$ & $01 \%$ & $1 / 494$ & 。 \\
\hline Rhmax & $-0 / 019$ & $\circ / 0 \circ \Delta$ & $-0 /|r|$ & $-14 / 994$ & 。 \\
\hline WS & $\circ / 4 Y \wedge$ & $0 / 001$ & o/rAr & $\Delta Q / \wedge 9 V$ & 。 \\
\hline Sun & $0 / 194$ & $0 / 001$ & $0 / Y_{01}$ & $r Q / \Delta r$ & 。 \\
\hline
\end{tabular}

مقادير بتا و سطح معنى دارى است. با مشاهدة سطح معنى دارى

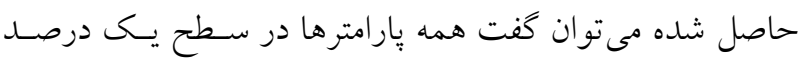

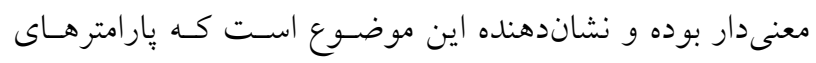

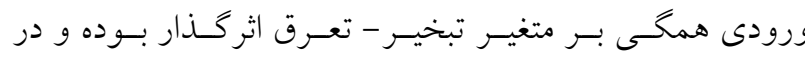

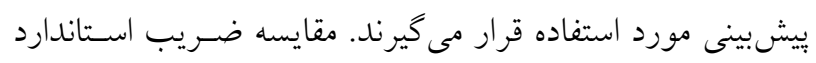

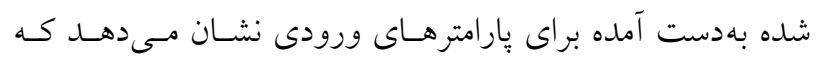

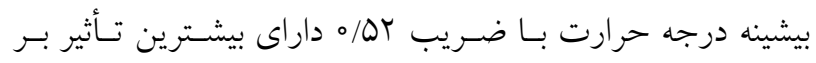

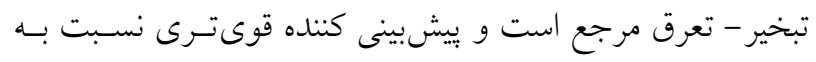

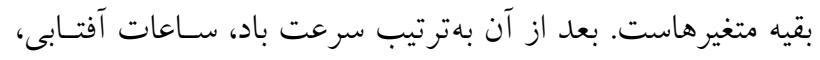

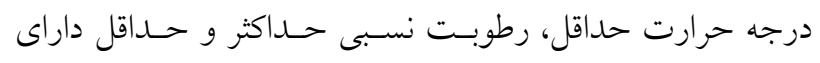

حرارت حداكثر، درجه حرارت حداقل، رطوبت نسبى حـداكثر،

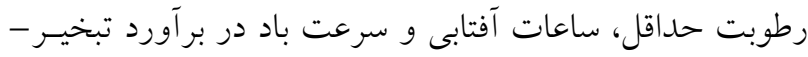

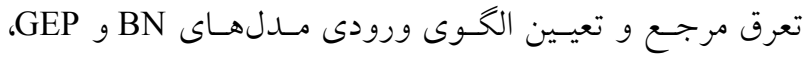

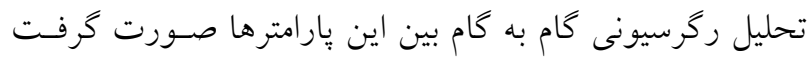

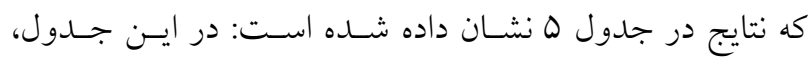

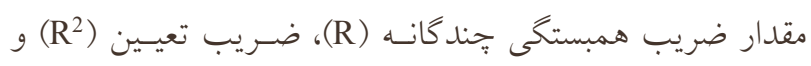

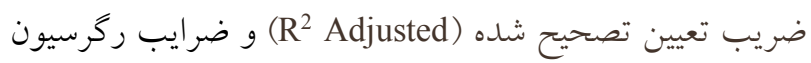

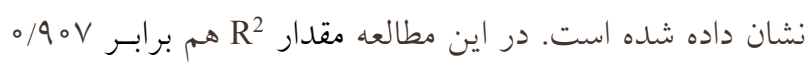

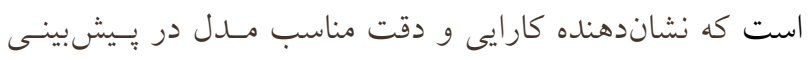

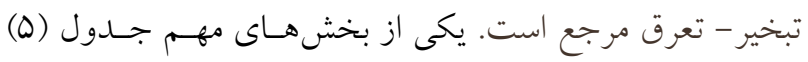


جدول و. روابط ركرسيونى بين تبخير - تعرق مرجع و يارامترهاى هواشناسى

\begin{tabular}{|c|c|c|}
\hline \multicolumn{2}{|c|}{ 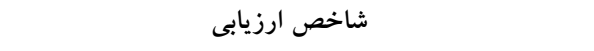 } & \multirow{2}{*}{ رابطه } \\
\hline 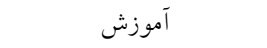 & 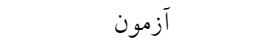 & \\
\hline $\mathrm{R}^{2}=0 / \Lambda_{0}, \mathrm{RMSE}=r / 11$ & $\mathrm{R}^{2}=0 / N r$ gMSE $=r / N 1$ & $\mathrm{ET}_{0}=-0 / \Delta \Delta \mathrm{r}+\circ / 1 \mathrm{r} \varphi \mathrm{Tmax}$ \\
\hline $\mathrm{R}^{2}=0 / \mathrm{N}, \mathrm{RMSE}=1 / 9$ & $\mathrm{R}^{2}=0 / \mathrm{V} \boldsymbol{Q}, \mathrm{RMSE}=\mathrm{r} / \mathrm{VA}$ & $\mathrm{ET}_{0}=-0 / \Delta \Delta r+0 / / r q \mathrm{Tmax}+0 / 4 \uparrow \wedge W \mathrm{WS}$ \\
\hline $\mathrm{R}^{2}=0 / \wedge 9, \mathrm{RMSE}=1 / \mathrm{TV}$ & $\mathrm{R}^{2}=0 / \mathrm{V} q, \mathrm{RMSE}=\mathrm{r} / \Gamma_{\Lambda}$ & 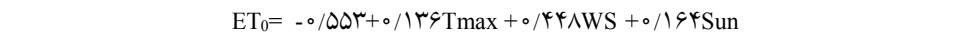 \\
\hline $\mathrm{R}^{2}=0 / 90, \mathrm{RMSE}=1 / \pi 9$ & $\mathrm{R}^{2}=0 / \Lambda_{0}, \mathrm{RMSE}=r / \kappa_{0}$ & 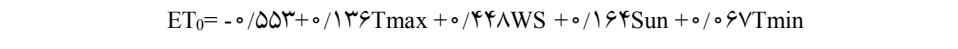 \\
\hline $\mathrm{R}^{2}=0 / 90, \mathrm{RMSE}=1 / \mu \mathrm{r}$ & $R^{2}=0 / \Lambda \circ, R M S E=r / 4 r$ & 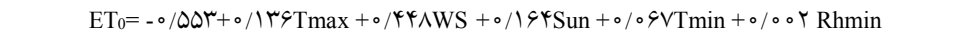 \\
\hline $\mathrm{R}^{2}=0 / 91, \mathrm{RMSE}=0 / 9$ & $\mathrm{R}^{2}=0 / \mathrm{N} Y \mathrm{RMSE}=T / Y 1$ & 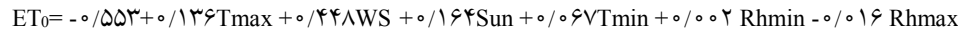 \\
\hline
\end{tabular}

در اين جدول، حداقل، Rhmin: رطوبت نسبى حداقل و Rhmax: رطوبت نسبى حداكثر هستند.

ســاختار تركيبـى شـماره † شــامل WS و

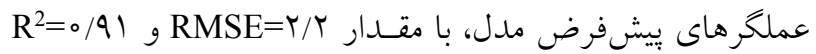

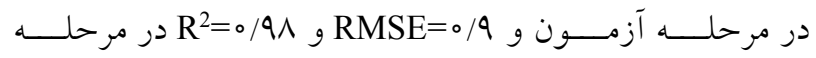
آموزش، داراى كمترين خطا و بيشـترين دقـت بـوده و تو انسـته است ميزان ET را با دقت مناسبى برآورد كند. در مقابل تركيب

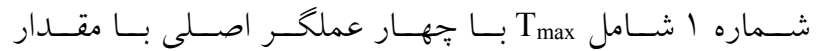
RMSE=r/4 و مر مرحله آزمــون و RMSE مر مرحله آموزش، داراى كمترين دقـت بـوده اسـت.

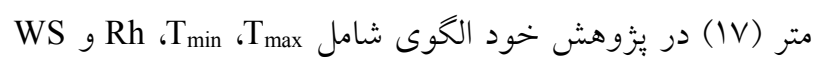

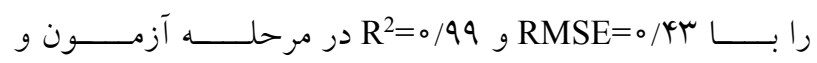

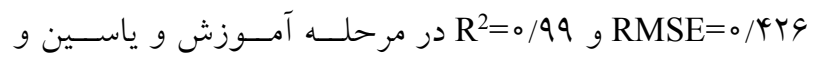

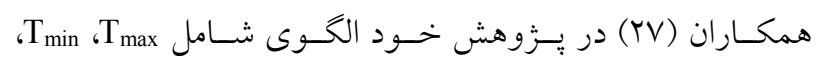

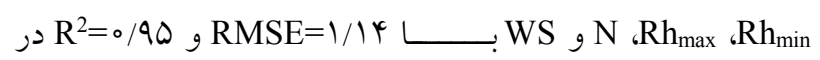

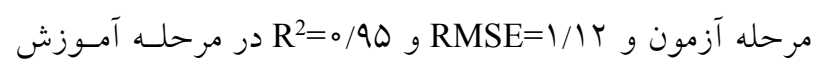
را بهعنوان مناسبترين مدل انتخاب كردند.

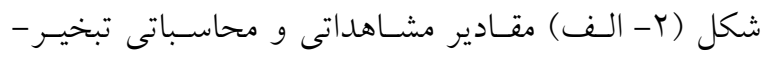

تعرق مرحله آموزش مدل را در طول دوره آمارى نشان مىدهد. همانطور كه مشاهده مىشود مدل توانسته است روند تغييـرات ET0 مشاهداتى در مقابل مقادير محاسباتى آمـوزش مــدل نسـبت بـه

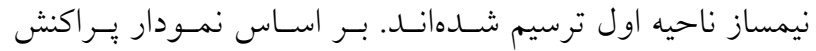
(قسمت ب) مشاهده مى شود كـه عملكـرد مــل مناسـب بـوده
بيشترين تأثير در يـيشبينسى و بــرآورد تبخيـر - تعـرق هسـتند. حسينى و همكاران (0 () نتيجه كرفتند كه بيشينه درجه حـرارت و سرعت باد بيشترين تأثير را بـر تبخيـر - تعـرق مرجـع داشـته

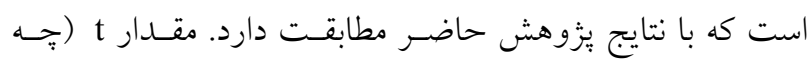

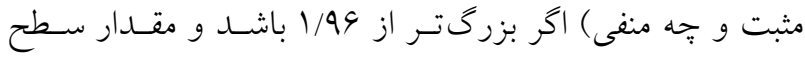

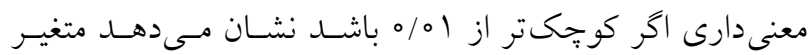

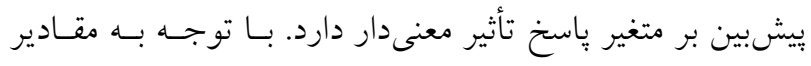
مربوط به هر شش متغيـر، همــهُ متغيرهـا داراى تـأثير معنسى دار هستند. جدول و نيز نشاندهنده رابطه رگرسيونى بـين پيارامترهـاى

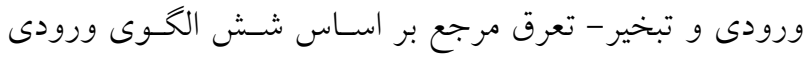

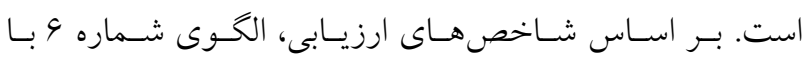
RMSE=r/T در مرحله آمـوزش و RMSE=0/9 و در مرحله آزمون بهعنوان مناسبترين الكو معرفى

GEP مدلسازى تبخير - تعرق مرجع بهوسيله

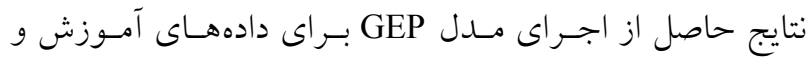
آزمون در شش الكوى ورودى بههمراه دو نوع عملكر رياضس، در جدول V ارائه داده شده است. همانطور كه مشاهلده مىشود، برنامهريزى بيان زن توانسته است در تمام سـناريوها عملكـرد و دقت مناسبى از خود ارائه دهد. در بين سناريوهاى انجـام شـده، 
جدول V. روش برنامهريزى بيان زن با استفاده از دو مجموعه عملكر رياضى

\begin{tabular}{|c|c|c|c|c|c|c|}
\hline \multicolumn{2}{|c|}{ آزمون } & \multicolumn{2}{|c|}{ آموزش } & \multirow{2}{*}{ عملحر } & \multirow{2}{*}{ الخو } & \multirow{2}{*}{ رديف } \\
\hline RMSE(mm/day) & $\mathrm{R}^{2}$ & RMSE(mm/day) & $\mathrm{R}^{2}$ & & & \\
\hline$K Y / Y$ & $\Lambda F / 。$ & $\mu / \Lambda$ & $9 \circ / 0$ & $\mathrm{~F} 1$ & \multirow{2}{*}{ M1 } & \multirow{2}{*}{1} \\
\hline T/TO & $\Lambda \varepsilon / \circ$ & $Y Y / I$ & $9 Y / 0$ & $\mathrm{~F} 2$ & & \\
\hline 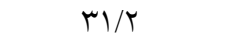 & $M N \circ$ & $1 / 1$ & $99 / 0$ & $\mathrm{~F} 1$ & \multirow{2}{*}{ M2 } & \multirow{2}{*}{ r } \\
\hline$T Y / T$ & $91 / 0$ & $9 r / 0$ & $9 \mathrm{~V} / 0$ & $\mathrm{~F} 2$ & & \\
\hline$Y Y / T$ & $\Lambda F / 。$ & $r / l$ & $91 / 0$ & $\mathrm{~F} 1$ & \multirow{2}{*}{ M3 } & \multirow{2}{*}{ r } \\
\hline$r \mid / T$ & $M / \circ$ & $14 / 1$ & $90 / \circ$ & $\mathrm{F} 2$ & & \\
\hline$T Y / T$ & $M N \circ$ & $\mid Y / 1$ & $99 / \circ$ & $\mathrm{F} 1$ & \multirow{2}{*}{ M4 } & \multirow{2}{*}{$r$} \\
\hline$r / T$ & $91 / 0$ & $9 / 0$ & $9 N / 0$ & F2 & & \\
\hline$r \varphi / T$ & $9 Y / 0$ & $\circ \mu / 1$ & $9 \mathrm{~V} / 0$ & $\mathrm{~F} 1$ & \multirow{2}{*}{ M5 } & \multirow{2}{*}{$\Delta$} \\
\hline$T G / T$ & $90 / 0$ & $04 / 1$ & $99 / 0$ & $\mathrm{~F} 2$ & & \\
\hline$r \Lambda / T$ & $\Lambda Q / \circ$ & $r Q / 1$ & $94 \%$ & $\mathrm{~F} 1$ & \multirow{2}{*}{ M6 } & \multirow{2}{*}{9} \\
\hline$T Y / T$ & $91 / 0$ & $9 \pi / 0$ & $90 / \circ$ & $\mathrm{F} 2$ & & \\
\hline
\end{tabular}

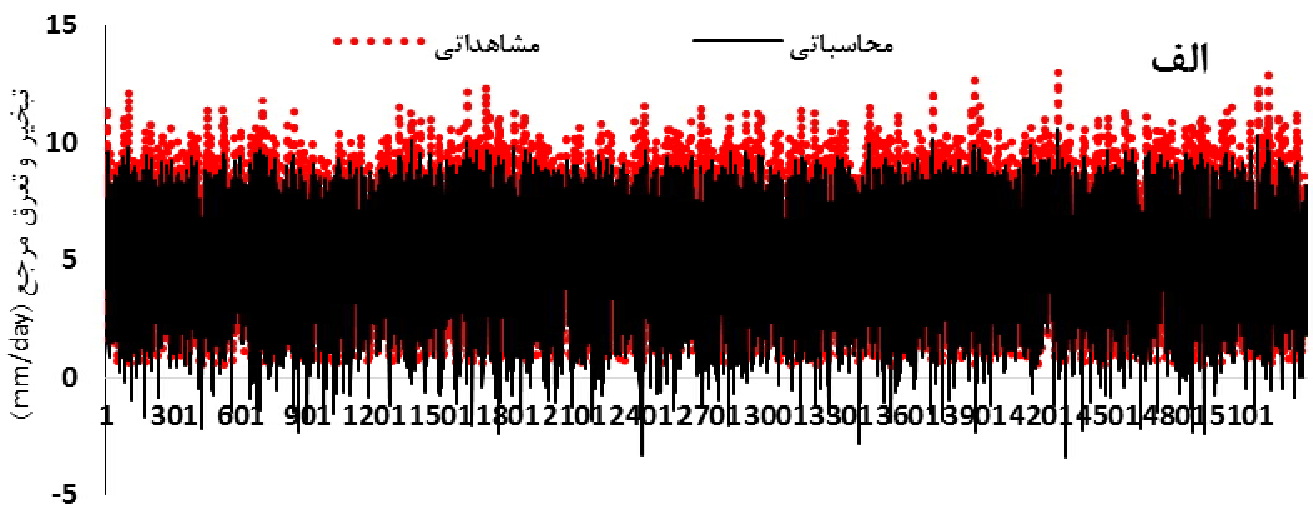

$$
\text { زمان (روز) }
$$

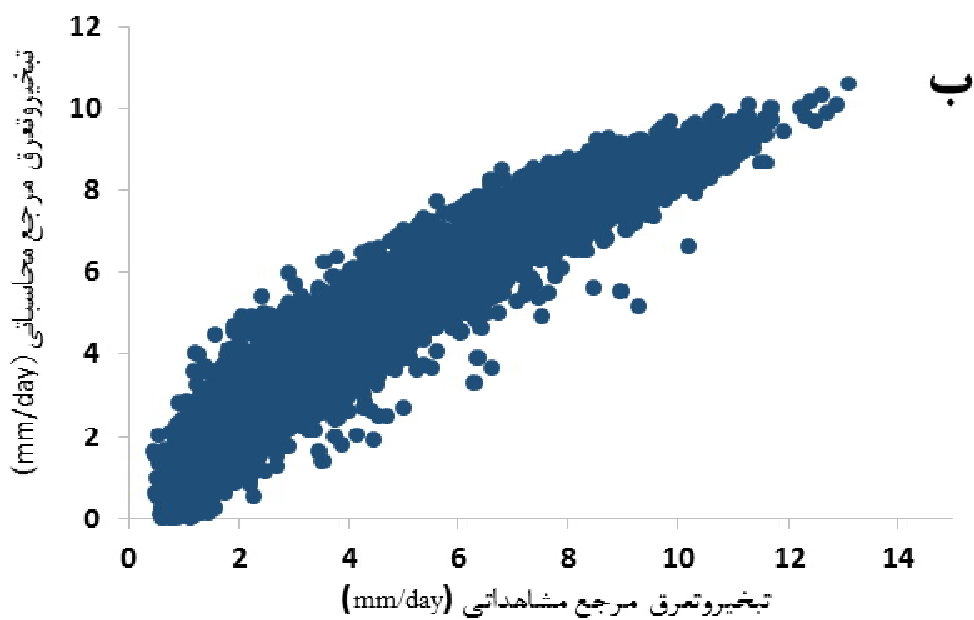

شكل r. نمودار حاصل از مقادير بهينه مدل برنامهريزى بيان زن براى دادههاى ثبت شده مرحله آموزش: الف) مقادير محاسباتى و مشاهداتى نسبت به زمان و ب) نمودار براكنش ميان مقادير مشاهداتى و محاسباتى 
جدول ^م نتايج حاصل از مدل شبكه بيزين

\begin{tabular}{|c|c|c|c|c|c|}
\hline \multicolumn{2}{|c|}{ آزمون } & \multicolumn{2}{|c|}{ آموزش } & \multirow[t]{2}{*}{ الخو } & \multirow[t]{2}{*}{ رديف } \\
\hline $\operatorname{RMSE}(\mathrm{mm} /$ day $)$ & $\mathrm{R} 2$ & RMSE(mm/day) & $\mathrm{R} 2$ & & \\
\hline$K Y / Y$ & $\Lambda \mu / 。$ & $r / \Lambda$ & $11 \%$ & M1 & 1 \\
\hline$\Lambda \mu / r$ & $\Lambda \varepsilon / \circ$ & $90 / 1$ & $\Lambda N / \circ$ & M2 & r \\
\hline 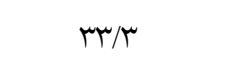 & $\Lambda N /$ & $G Y / T$ & $19 / \circ$ & M3 & r \\
\hline $0 \mu / \mu$ & $\wedge 9 / \circ$ & $T V / T$ & $9 \% \%$ & M4 & 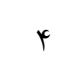 \\
\hline & $91 \%$ & $T / Y$ & $90 \%$ & M5 & 0 \\
\hline$T G / T$ & $9 \% / 0$ & $.1 / 1$ & $91 / 0$ & M6 & 4 \\
\hline
\end{tabular}

مدلسازى تبخير - تعرق مرجع بهوسيله شبكه بيزين

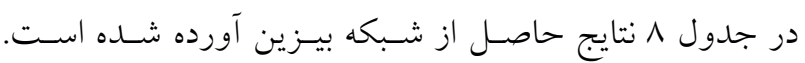

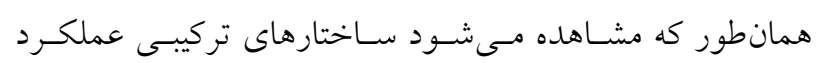

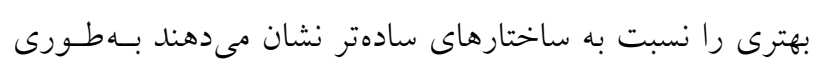

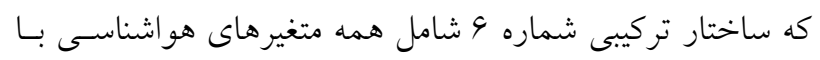

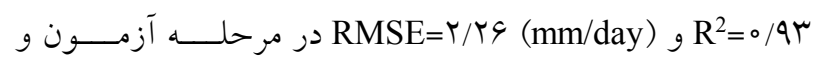

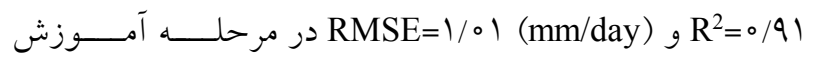

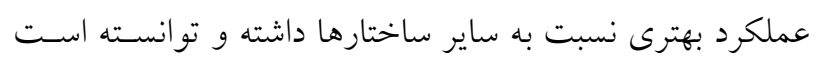

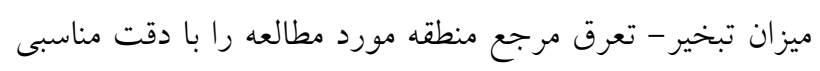

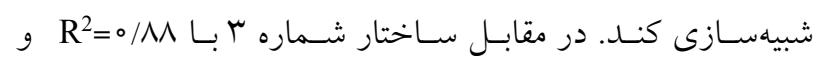

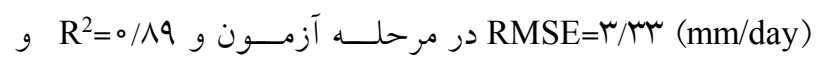

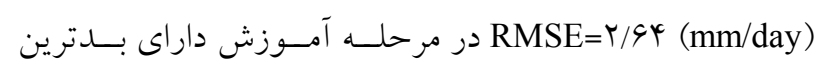
عملكرد بوده است.

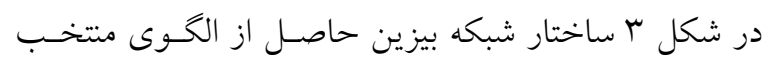

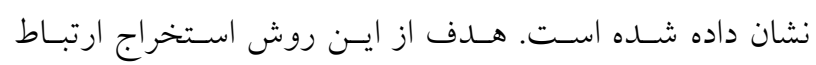

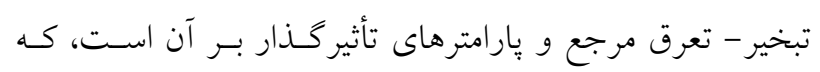
درنهايت منجر به ارائه رابطه ه ما شد. ET0 $=0.133635 * \mathrm{~T}_{\max }+0.445122 * \mathrm{WS}$

$0.161776 *$ SolarRadiation $+0.0685841 * \mathrm{~T}_{\text {min }^{-}}$

$0.0151305 * \mathrm{Rh}_{\max }+\operatorname{Normal}(-0.471033,0.902415)$

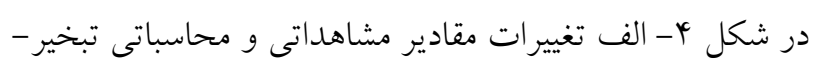

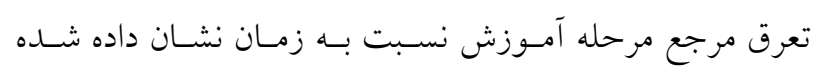

بهطورى كه در اكثر موارد، مقادير محاسباتى و يسيشبينسى شــده

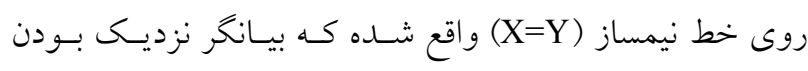

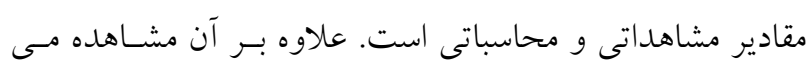

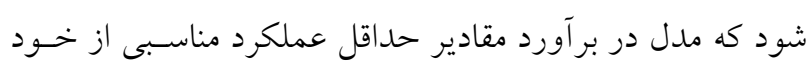

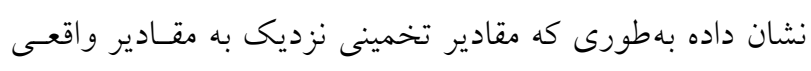

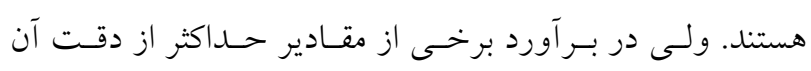

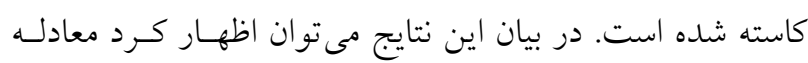

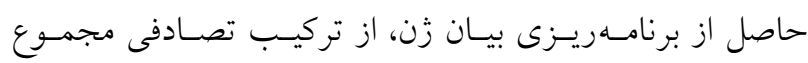

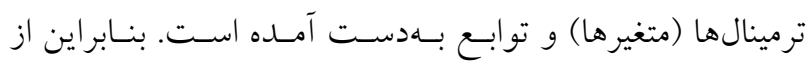

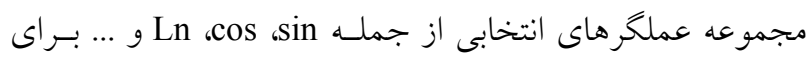

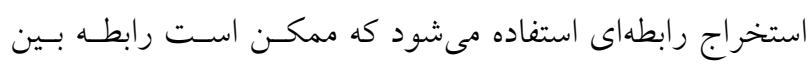

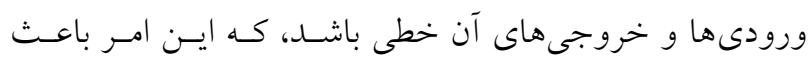
كاهش دقت مدل شده است.

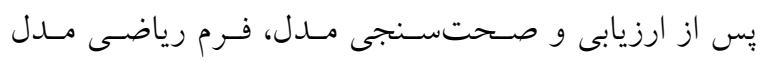

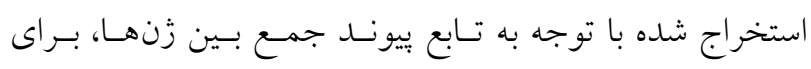

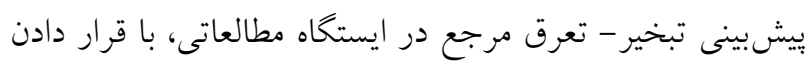

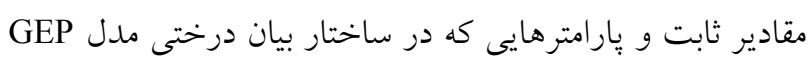

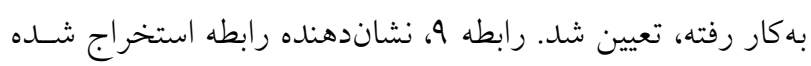

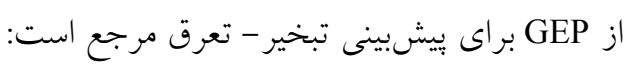

ET0 $=\operatorname{atan}(-4.77)+\quad \operatorname{atan}(\operatorname{atan}((\operatorname{atan}(\mathrm{WS})-$ $\tanh ($ gepMax2 $((\operatorname{Tmax}-\mathrm{N}),-10.01)))))+((((\mathrm{N}+($ WS$\mathrm{N})) / 2)+((((\mathrm{WS}+\mathrm{Tmin}) / 2)+((\operatorname{Tmax}+\mathrm{N}) / 2)) / 2)) / 2) \quad$ (9) 


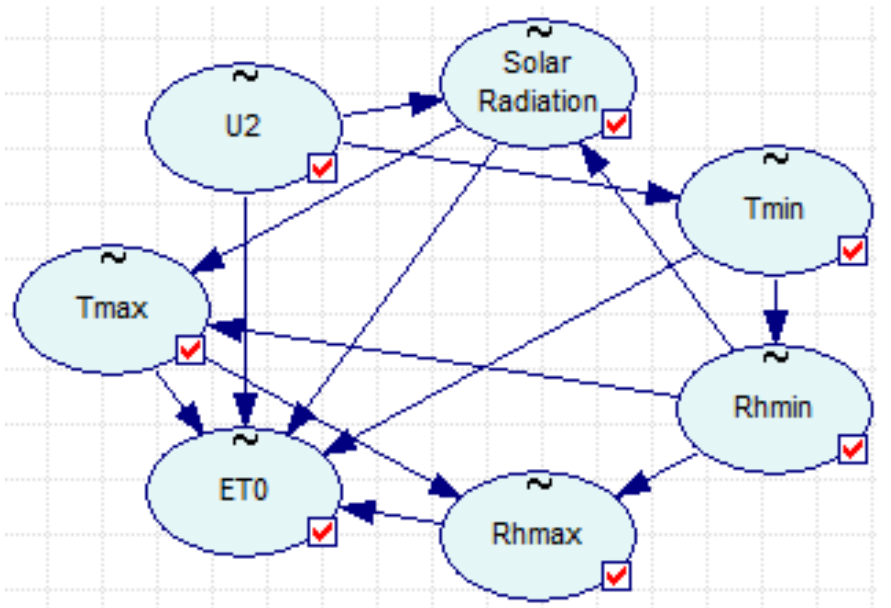

شكل r. ساختار شبكه بيزين به كار رفته براى شبيهسازى
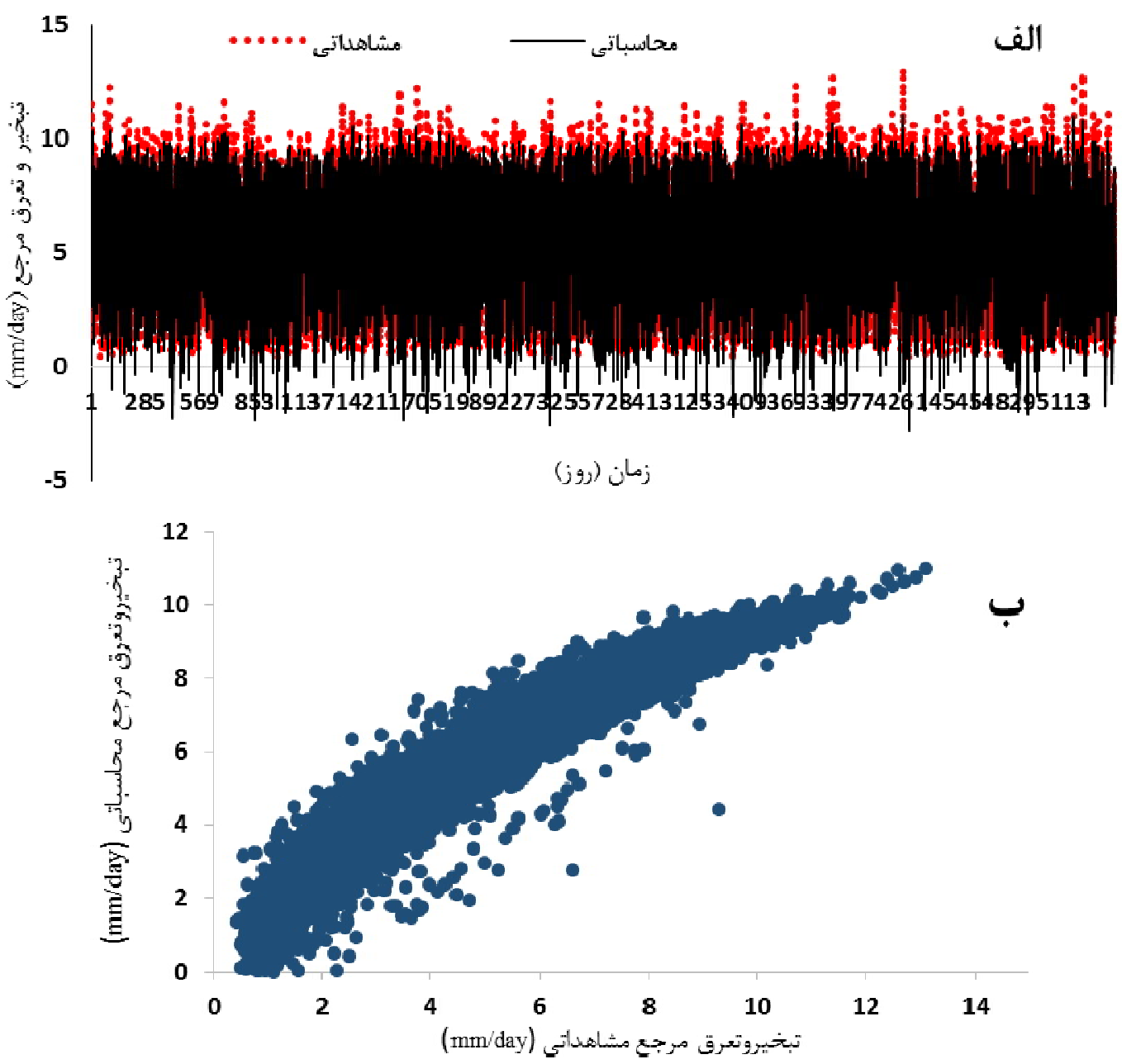

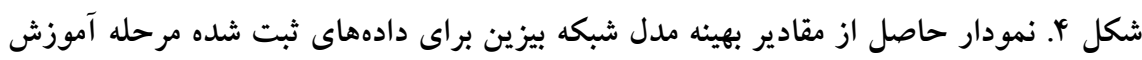

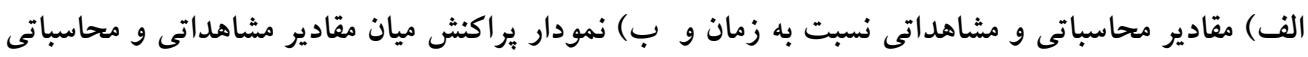


جدول 9. مقادير شاخصهاى خطاسنجى مدلهاى برنامهريزى بيان زن، شبكه بيزين و رگرسيون كام به گام

\begin{tabular}{|c|c|c|c|c|}
\hline$\overline{\mathrm{MR}}$ & $\overline{\text { AARE }}$ & $\mathrm{R}^{2}$ & RMSE (mm/day) & نام مدل \\
\hline.$/ 94$ & $0 / 1 Y$ &.$/ 9 \Lambda$ & $0 / 9$ & برنامهريزى بيان زن \\
\hline$\circ / 90$ & $0 / r$ &.$/ 91$ & $1 / 01$ & شبكه بيزين \\
\hline.$/ 9 T$ &.$/ 14$ & $0 / 91$ & $\circ / 9$ & رگرسيون كام به كام \\
\hline
\end{tabular}

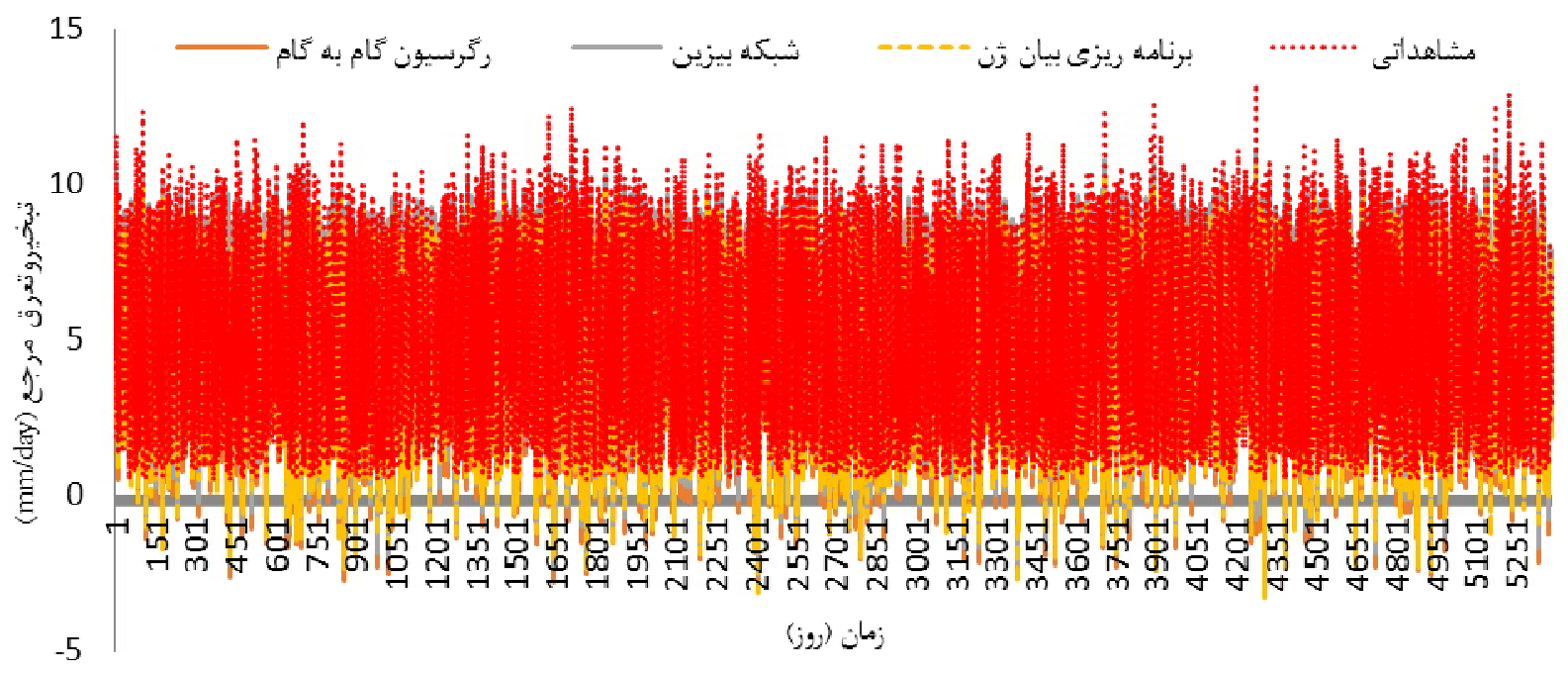

شكل ه. نمودار مقادير محاسباتى و مشاهداتى مدلهاى مختلف نسبت به زمان

رخرسيون گام به گام در مرحله آموزش اسـت. بــر اسـاس ايسن

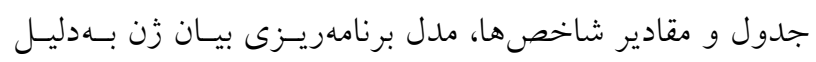

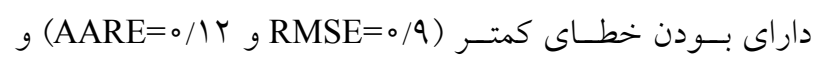

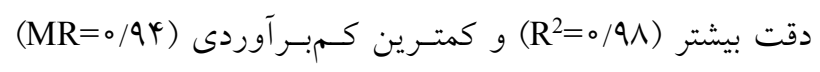

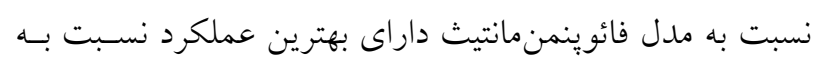

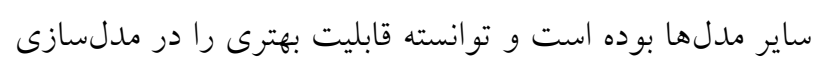
ET0

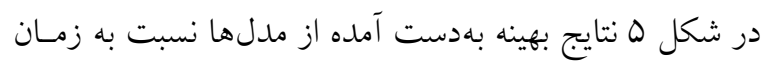

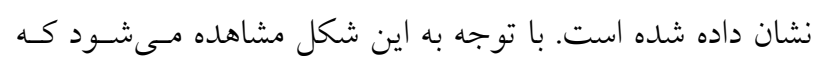

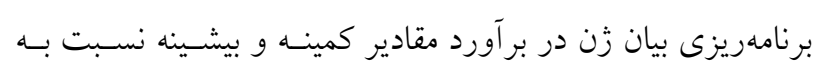

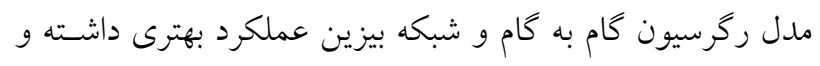

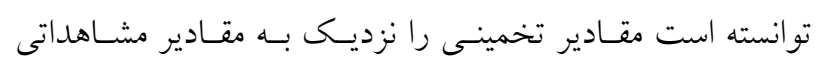

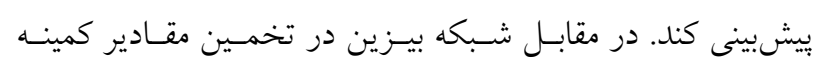
عملكرد خوبى نداشته و نتوانسته است دقت مناسبى را ارائه دهد.
است. شكل ץ- ب نمودار يـر اكنش مقــادير تخمينسى و مقـادير محاسباتى نسبت به نيمساز ربع اول را نشان مى دهد. همانطسور

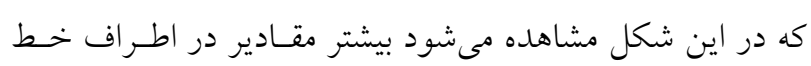

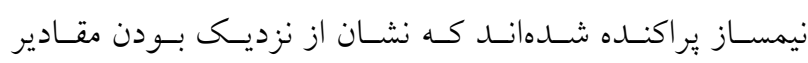

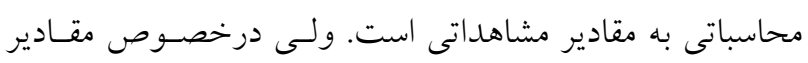

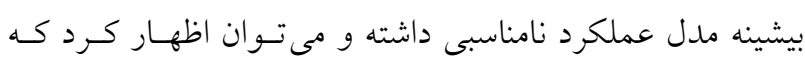

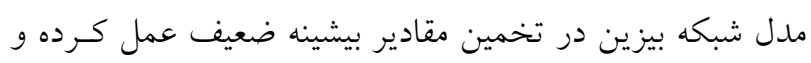

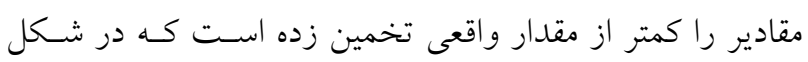
قابل ملاحظه است.

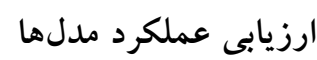
در اين بخش به ارزيابى دقت و عملكرد مدلهاى مورد استفاده

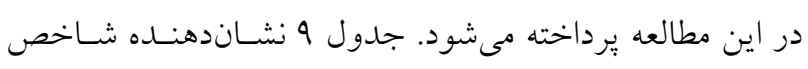

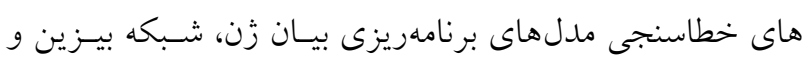




$$
\begin{aligned}
& \text { تخمين مقادير خروجى است كه تعداد دادههــا بـراى آمـوزش } \\
& \text { شبكه بيشتر شده و شبكه به خوبى تعميم داده شـود. هم:جنسين } \\
& \text { مدلهاى مبتنى بر برنامهريزى بيان زن راهحل هايى را ارائه مى - } \\
& \text { كنند كه مى توان رابطـهـ بـين متغيرهـاى ورودىى و خروجـى را } \\
& \text { مشخص كرد. كفتنى است كـه در خصـوص تركيـبـهـايى بـا } \\
& \text { متغيرهاى كمتر نيز مدلها جوابـهاى خوبى ارائـه كردنــ كـهـ }
\end{aligned}
$$

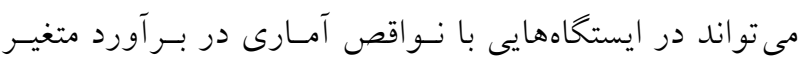

$$
\begin{aligned}
& \text { مورد نظر مورد استفاده قرار كيرند. نتايج حاصل از معيارهـاى } \\
& \text { ارزيابى نشان داد مدل برنامهريزى بيان زن دقت بالايى نسـبت } \\
& \text { به مدلهاى تجربى، ركرسيون كام بـه گـام و شـبكه بيـزين از } \\
& \text { خود نشان داده است. در يايان بيششنهاد مىشـود، از روشهـاى } \\
& \text { جديدتر مانند تئسورى بـازىهـا در تعيـين متغيرهـاى مـؤثر و } \\
& \text { الكوهاى ورودى مدل سـازى و از روشهــاى نـوين هوشـمند }
\end{aligned}
$$

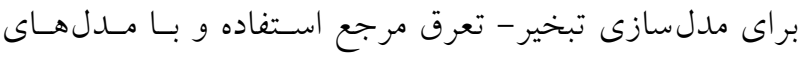

$$
\begin{aligned}
& \text { قديمى تر مقايسه شود. }
\end{aligned}
$$

در اين بززوهش عملكرد مدلهاى تجربسى، رگرسـيون گَام بـهـ كام، برنامهريزى بيان زن و شبكه بيزين براى بــرآورد تبخيـر -

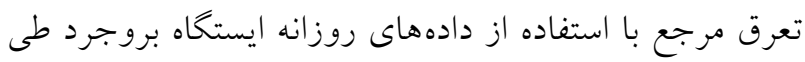
دوره زمانى هV تعرق مرجع بيشبينى شده در مــلهــاى مـذكور، بـر اسـاس

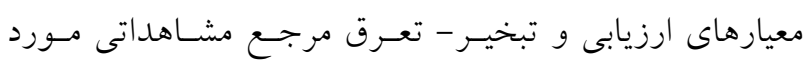

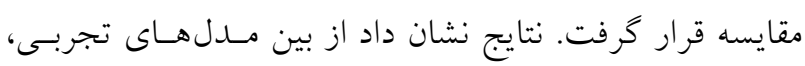
مدل كيمبرلى ينمن در ايستخاه مطالعاتى داراى عملكرد بهتـرى است. نتايج بهدست آمده از اجـراى مــلهــا بـا سـاختارهاى

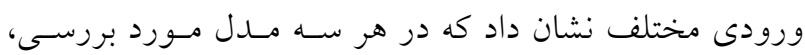
ساختارهاى تركيبى از عملكرد بهتـــى برخـوردار هسـتند كـهـ

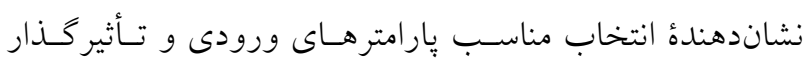
بودن آنها در مدلسازى بوده اسـت. از طرفى افـزايش تعـداد متغيرهاى مؤثر در ورودى موجب كسترش حافظه مــل بـراى

\section{منابع مورد استفاده}

1. Aguilera, P. A., A. Fernández, R. Fernández, R. Rumí and A. Salmerón. 2011. Bayesian networks in environmental modelling. Environmental Modelling \& Software 26(12): 1376-1388.

2. Akhoni Pourhoseini, F. and A. Asadi. 2017. Application of Bayesian Network and Support Vector Machine in predicting of water table changes (case study: Ardabil plain). Iran-Watershed Management Science \& Engineering 11(36): 33-42.

3. Allen, R. G., L. S. Pereira, D. Raes and M. Smith. 1998. Crop evapotranspiration-guidelines for computing crop water requirements-FAO Irrigation and drainage paper 56. FAO, Rome 300(9): D05109.

4. Almorox, J., V. H. Quej and P. Martí. 2015. Global performance ranking of temperature-based approaches for evapotranspiration estimation considering Köppen climate classes. Journal of Hydrology 528: 514-522.

5. Blaney, H. F. and W. D. Criddle. 1950. Determining Water Requirements in Irrigated Areas from Climatological and Irrigation Data; Soil Conservation Service Technical Paper 96; Soil Conservation Service, US Department of Agriculture: Washington, DC, USA.

6. Chen, D., X. Wang, S. Liu, Y. Wang, Z. Gao, L. Zhang and X. Wei. 2015. Using Bayesian analysis to compare the performance of three evapotranspiration models for rainfed jujube (Ziziphus jujuba Mill.) plantations in the Loess Plateau. Agricultural Water Management 159: 341-357.

7. Davies, P. E. 2007. Bayesian decision networks for management of high conservation assets (national water Initiative-Australian government water fund. Report 6/6 Report to the Conservation of Freshwater Ecosystem Values Project, Water Resources Division, Department of Primary Industries and Water).

8. Ferreira, C. 2001. Gene expression programming: a new adaptive algorithm for solving problems. arXiv preprint cs/0102027.

9. Hargreaves, G. L. and Z. A. Samani. 1985. Reference crop evapotranspiration from temperature. Journal of Applied Research in Water Sciences 1: 96-99.

10. Hosseini S., N. Ganji Khoramdeln and A. H. Khalat Abadi Farahani. 2015. Evaluation and sensitivity analysis of different methods of estimating daily reference evapotranspiration in a cold climate. Journal of Applied Research in Water Sciences 1(2): 29-40. (In Farsi).

11. Khoshhal, J., H. Zareabyane, A. R. Joshani and M. Khazaee. 2017. Evaluation of different potential 
evapotranspiration methods with pan-FAO model in East and Northeast of Iran. Journal of Natural Geography 8(28): 1-16. (In Farsi).

12. Kool, D., N. Agam, N. Lazarovitch, J. L. Heitman, T. J. Sauer and A. Ben-Gal. 2014. A review of approaches for evapotranspiration partitioning. Agricultural and Forest Meteorology 184: 56-70.

13. Legates, D. R. and G. J. McCabe. 1999. Evaluating the use of "goodness-of-fit" measures in hydrologic and hydroclimatic model validation. Water Resources Research 35(1): 233-241.

14. Lerner, U., R. Parr, D. Koller and G. Biswas. 2000. Bayesian fault detection and diagnosis in dynamic systems. In Aaai/Iaai 531-537.

15. Makkink, G. F. 1957. Testing the Penman formula by means of lysimeters. Journal of Institution Water Engineering 11: 277-288.

16. Martí, P., P. González-Altozano, R. López-Urrea, L. A. Mancha and J. Shiri. 2015. Modeling reference evapotranspiration with calculated targets. Assessment and implications. Agricultural Water Management 149: 8190.

17. Mattar, M. A. 2018. Using gene expression programming in monthly reference evapotranspiration modeling: a case study in Egypt. Agricultural Water Management 198: 28-38.

18. Mehdizadeh, S., J. Behmanesh and K. Khalili. 2017. Using MARS, SVM, GEP and empirical equations for estimation of monthly mean reference evapotranspiration. Computers and Electronics in Agriculture 139: $103-114$.

19. Priestley, C. H. B. and R. J. Taylor. 1972. On the assessment of surface heat flux and evaporation using large-scale parameters. Monthly Weather Review 100(2): 81-92.

20. SadeghiHesar, A, H. Tabatabaee and M. Jalali. 2012. Monthly rainfall forecasting using Bayesian belief networks. International Research Journal of Applied and Basic Sciences 3: 2226.

21. Shiri, J. 2017. Evaluation of FAO56-PM, empirical, semi-empirical and gene expression programming approaches for estimating daily reference evapotranspiration in hyper-arid regions of Iran. Agricultural Water Management 188: 101-114.

22. Shiri, J., A. H. Nazemi, A. A. Sadraddini, G. Landeras, O. Kisi, A. F. Fard and P. Marti. 2014. Comparison of heuristic and empirical approaches for estimating reference evapotranspiration from limited inputs in Iran. Computers and Electronics in Agriculture 108: 230-241.

23. Sun, H., Y. Yang, R. Wu, D. Gui, J. Xue, Y. Liu and D. Yan. 2019. Improving estimation of cropland evapotranspiration by the Bayesian model averaging method with surface energy balance models. Atmosphere, 10(4): 188.

24. Turc, L. 1961. Estimation of irrigation water requirements, potential evapotranspiration: A simple climatic formula evolved up to date. Annals Aggronomiques 12: 13-49.

25. Valipour, M., G. Sefidkouhi, M. Ali, M. Raeini-Sarjaz and S. M. Guzman. 2019. A hybrid data-driven machine learning technique for evapotranspiration modeling in various climates. Atmosphere 10(6): 311.

26. Wright, J. L. and M. E. Jensen. 1972. Peak water requirements of crops in Southern Idaho. Journal of Irrigation and Drainage Engineering ASCE 96(1): 193-201.

27. Yassin, M. A., A. A. Alazba and M. A. Mattar. 2016. Artificial neural networks versus gene expression programming for estimating reference evapotranspiration in arid climate. Agricultural Water Management 163: 110124.

28. Zhang, B. Z., Y. Liu, D. Xu, N. N. Zhao, B. Lei, R. D. Rosa, P. Paredes, T. A. Paco and L. S. Pereira. 2013. The dual crop coefficient approach to estimate and partitioning evapotranspiration of the winter wheat-summer maize crop sequence in North China Plain. Irrigation Science 31(6): 1303-1316. 


\title{
Evaluation of Experimental Models and Artificial Intelligence in Estimation of Reference Evapotranspiration (Case Study: Boroujerd Station)
}

\author{
Y. Sabzevari ${ }^{1}$ and M. Saeidnia ${ }^{2^{\star}}$
}

(Received: April 20-2020 ; Accepted: November 17-2020)

\begin{abstract}
The FAO Penman-Monteith is a baseline method to estimate reference evapotranspiration. In many cases, it is difficult to access all data, so replacing simpler models with lower input data and appropriate accuracy is necessary. The purpose of this study is to investigate the capability of the experimental models, gene expression programming, stepwise regression, and Bayesian network in estimating reference evapotranspiration. In this research, daily information of the Boroujerd synoptic station in the period of $1996-2017$ was used as model inputs. Based on the correlation between input and output parameters, six input patterns were determined for modeling. The results showed that the Kimberly-Penman model has the best performance among the experimental models. Gene expression programming with fourth pattern and Default Model Operators $\left(\mathrm{R}^{2}=0.98\right.$ and RMSE $\left.=0.9\right)$, Bayesian Network with sixth pattern $\left(\mathrm{R}^{2}=0.91\right.$ and $\left.\mathrm{RMSE}=1.01\right)$, and stepwise regression with sixth pattern have the most accurate patterns at $\mathrm{R}^{2}=0.91$ and $\mathrm{RMSE}=0.9$ in the training stage. Comparison of the performance of the three models showed that the gene expression programming model was superior to the other two models with the Average Absolute Relative Error (AARE) of 0.12 and the Mean Ratio (MR) of 0.94. The results showed that gene expression programming had an acceptable ability to estimate reference evapotranspiration under the weather conditions of Boroujerd and could be introduced as a suitable model.
\end{abstract}

Keywords: FAO-Penman-Monteith, Reference evapotranspiration, Bayesian network, Gene expression programming

1. Department of Water Engineering, Faculty of Agriculture, Isfahan University of Technology, Isfahan, Iran.

2. Department of Water Engineering, Faculty of Agriculture and Natural Resources, Lorestan University, Lorestan, Iran.

Corresponding author, Email: Saeedinia.m@lu.ac.ir 